\title{
THE CURRENT SITUATION AND PRACTICE OF WILDLIFE MANAGEIMENT IN THE UNITED STATES AND CHINA
}

\author{
Xiaoxia Du' ${ }^{1}{ }^{*}$, Weiwei Zhou ${ }^{1}$, Hongmei Xie ${ }^{1}$, Xin Wang ${ }^{2}$, Meiqing $\mathrm{Li}^{1}$, Fengrong Zhang ${ }^{1}$ and Bayi Jiang ${ }^{1}$, \\ ${ }^{1}$ Shandong Vocational Animal Science and Veterinary College, Weifang, China \\ ${ }^{2}$ Yantai Vocational College, Yantai, China \\ *Corresponding author: duxiaoxia0931@126.com (DXX); sdmyxyjby@163.com (JBY)
}

\section{INTRODUCTION}

COVID-19 has become a serious infectious disease threatening all the people on the earth. It has been the second pandemic in 21st century (Mallah et al. 2021), with over 185 million infections and over 4 million deaths till July 9, 2021 (Chinanews 2021). According to codon usage studies, the novel virus has been transferred from an animal source (such as bats) to humans (Dhama et al. 2020), but there is yet no evidence of direct bat-to-human transmission of coronavirus infection (Frutos et al. 2021). In recent decades (1998-2018), about 421 million threatened (CITES-listed) wild animals were traded between 226 countries or territories (Liew et al. 2021). In the world, many nations and regions have taken measures to prevent and control COVID-19 by declaring a state of emergency, unprecedented quarantine, social distancing, and border closing efforts (Stawicki et al. 2020), but it is still difficult to control the pandemic.

Nowadays, humans are still suffering from the big disaster of COVID-19, and our life has been totally changed after the new virus came to the world. Therefore, all the governments and scientists need to pay more attention to the efficient wildlife management in order to keep human and wildlife harmony on the earth. Moreover, besides the COVID-19 pandemic, the global climate change and pollution are also threatening the public health. The climate change can influence the distribution, life cycle, and physiological status of hosts, pathogens and vectors, and it can drive novel cross-species viral transmission (Keatts et al. 2021). It should be noted that how to be friendly with the natural environment for humans and how to reduce the conflict between human and wildlife? Some scientific concepts, current threatening aspects for public health, cases for conflicts between human and wildlife, practice for wildlife management in the US and current situation of wildlife management in China are discussed in this chapter.

\section{SCIENTIFIC DEFINITIONS AND EXPLANATIONS}

\section{Wildlife}

Wildlife includes all free-ranging animals and plants in ecosystems and do not depend directly on humans for their livelihood; this is a broader definition (Abd Rabou 2020; Bailey 1984). For a refined definition, wildlife is limited to terrestrial vertebrates (Fryxell et al. 2014), including mammals, birds, reptiles, amphibians, and fish, which is wildly used (Bailey 1984). In the past, wildlife was considered game animals that were hunted, in another word, "wildlife" was similar with game: the mammals and birds were hunted for sport in 1960s (Bailey 1984). However, the definition of the wildlife is not universally accepted; it could be changed with the viewpoint of the user by the researchers and scientists. In general, the wildlife profession considers that wildlife are free-living, wild animals (excluding feral or exotic species) of major significance to humans. This definition also includes the associated plants and lower animals (e.g., microorganisms) because wildlife habitats that support wildlife should be considered. Wildlife and their habitats are interlocked and cannot be considered separately (Krausman and Cain 2013).

The above noted different definitions for wildlife from researchers can help us to understand the implication and extension of "wildlife". In fact, all animals had lived in the wild environment for long time, only some were domesticated purposely or unintentionally to meet the requirements in our daily life, such as guarder, food (meat, eggs, milk), warming (fur, skin) for human until now. Dog was the first wild animal domesticated by humans about 15,00o years ago in Eurasia, followed by sheep, goat, humpless cattle, pig and cat etc. as shown in Table 1. Other data about the evolution of wildlife, and the wildlife domestication in the different continents are also available (Figure 1; Table 2).

\section{Wildlife management}

Wildlife management involves many aspects in practice. Conservation, sustained yield, and control are three main areas in wildlife management (Fryxell et al. 2014). Bailey defined "Wildlife management as the art of utilizing land for the production of wildlife populations for harvest or other values" (Bailey 1984). Wildlife management includes a series of decisions - whether to have a hunting season (in the US) or not, whether to plant crops and trees, whether to invest in a game-check station or on a forage survey, whether to improve current wildlife habitats or to purchase more lands (Bailey 1984). Moreover, wildlife management also includes controlling the population size, distribution, and quality of wildlife, and manipulating hunting seasons directly or wildlife habitat indirectly. Ideally, wildlife managers would have unlimited budgets and would know all they needed to 


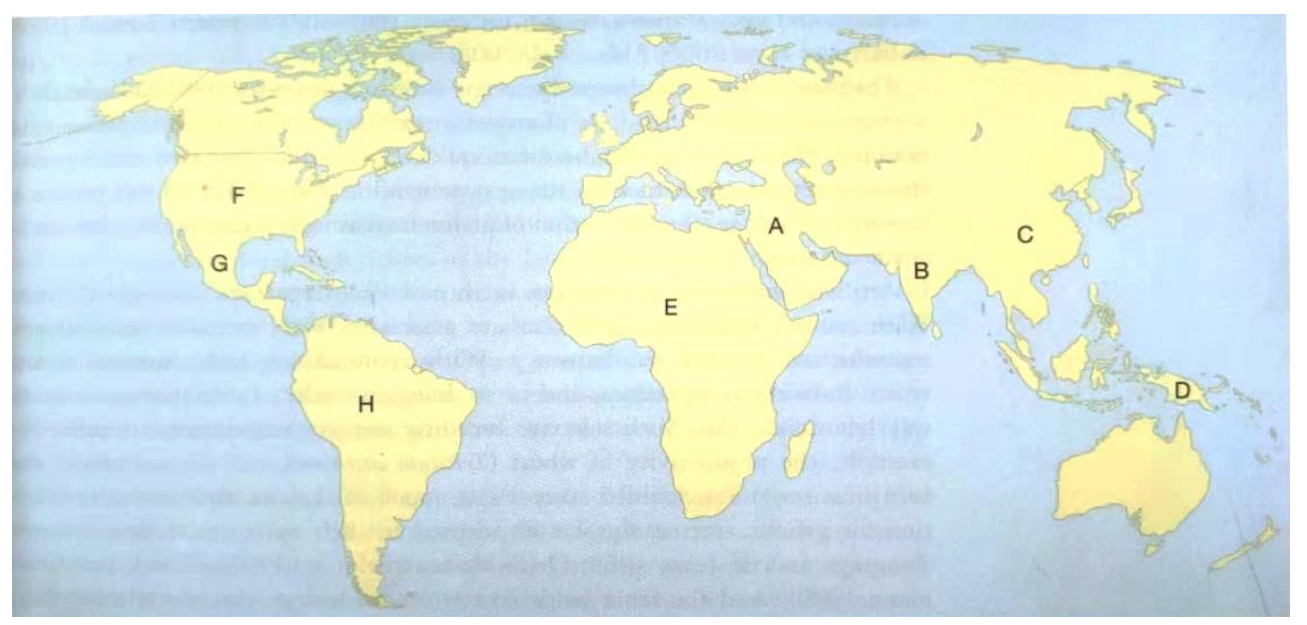

Figure 1: A map showing location where at least one animal domestication event is thought to have occurred. "A" is Southwest Asia, "B" is South Asia, "C" is East Asia, "D" is New Guinea, "E" is East Africa \& South Arabia, "F" is North America, "G" is MesoAmerica, "H" is South America. No animal was domesticated in B and F in this map, only plants were domesticated there (Bergstrom and Dugatkin 2016).

Table 1: The time frame and geography of domestication for key vertebrate domestic species (MacHugh et al. 2017)

\begin{tabular}{|c|c|c|c|}
\hline Common name & Scientific name & $\begin{array}{c}\text { Approximate time frame for } \\
\text { domestication (years before present) }\end{array}$ & Geographical location \\
\hline Dog & Canis familiaris & 15,000 & Eurasia \\
\hline Sheep & Ovis aries & 11,000 & Southwest Asia \\
\hline Goat & Capra bircus & 10,500 & Southwest Asia \\
\hline Humpless cattle (taurine) & Bos taurus & 10,300 & Southwest Asia \\
\hline Pig & Sus scrofa & 10,300 & Southwest Asia \\
\hline Cat & Felis catus & 9,500 & Southwest Asia \\
\hline Humped cattle (zebu) & Bos indicus & 8,000 & South Asia \\
\hline Water buffalo & Bubalus bubalis & 4,500 & South Asia \\
\hline Pig & Sus scrofa & 8,000 & East/Southeast Asia \\
\hline Chicken & Gallus gallus & 4,0oo & East/Southeast Asia \\
\hline Duck & Anas platyrbyncbos & 1,000 & East/Southeast Asia \\
\hline Horse & Equus caballus & 5,500 & Central Asia \\
\hline Bactrian camel & Camelus bactrianus & 4,500 & Central Asia \\
\hline Dromedary camel & Camelus dromedarius & 3,000 & Arabian Peninsula \\
\hline Donkey & Equus asinus & 5,500 & North Africa \\
\hline Llama & Lama glama & 6,000 & South America \\
\hline Alpaca & Vicugna pacos & 5,000 & South America \\
\hline
\end{tabular}

Table 2: The period and location where the animals were domesticated (Bergstrom and Dugatkin 2016).

\begin{tabular}{lcl}
\hline Species of Domestication & Probable Period of domestication & Geographic regions in the map \\
\hline Sheep & $8000-9800$ & A. Southwest Asia \\
Goat & $8000-9800$ & A. Southwest Asia \\
Pig & $9000-10200$ & A. Southwest Asia \\
Cattle (taurine) & $8000-10200$ & A. Southwest Asia \\
Cat & 4000 & A. Southwest Asia \\
Cattle (zebu) & $6300-8000$ & B. South Asia \\
Water buffalo & 4400 & B. South Asia \\
Pig & $6000-8400$ & C. East Asia \\
Silkworm & 5200 & C. East Asia \\
Yak & 4200 & C. East Asia \\
Horse & $4000-5400$ & C. East Asia \\
Bactrian camel & 4400 & C. East Asia \\
Duck & 1000 & C. East Asia \\
Chicken & 4000 & C. East Asia \\
Cattle (taurine) & $6400-7800$ & E. East Africa \& South Arabia \\
Donkey & $3400-5500$ & E. East Africa \& South Arabia \\
Dromedary camel & 3000 & E. East Africa \& South Arabia \\
Guinea fowl & 1400 & E. East Africa \& South Arabia \\
Turkey & 2000 & G. MesoAmerica \\
Llama & $4000-6000$ & H. South America \\
Alpaca & $3000-5000$ & H. South America \\
Guinea pig & $4000-5000$ & H. South America \\
Muscovy duck & $2000-3900$ & H. South America \\
\hline
\end{tabular}


know about their target populations and habitats. Leopold (1933) described the historical development of wildlife management in the United States and elsewhere in the following sequence: i) restriction of harvest, ii) control of competing predators, iii) establishment of refuges, iv) restocking, game farming, and transplanting, and v) habitat management; Bailey (1984) added vi) informing and communicating with the public and other land users (Bailey 1984).

Wildlife managers pay attention to manage habitats, including plants and invertebrates that could serve as foods or disease vectors for vertebrates. However, the aims of most wildlife management programs are to control the abundance of distribution and population size of vertebrates. It becomes more difficult to manage all the wildlife on the earth nowadays because so many species had been captive in the zoos or wildlife farms, which caused so serious contagious diseases in the world, such as COVID-19.

\section{Ecological and Economic Carrying Capacity}

Ecological Carrying Capacity (ECC 1 ) is one of the most important and common terms in wildlife management. The $\mathrm{ECC}_{1}$ can be regarded abstractly as the $\mathrm{K}$ in the logistic equation. In fact, it is set to be the limit of natural resources for a population of wildlife in a particular environment (Fryxell et al. 2014). It is an equilibrium point that a wildlife population tends to through densitydependent effects because of shortage of food supply, habitat (e.g. territoriality), cover, or other resources. If the wild environment changes, it would cause the population to deflect from equilibrium and produce fluctuations about the equilibrium. The environment change for a long time would affect resources, which in turn changes K. In other words, the population changes would be followed by the environmental trend. Predators, parasites, or diseases can regulate the size of population and form other equilibria. In order to distinguish the equilibrium produced by limited resources, predation, and by a combination of the two, whether resources limitation or predators or both affect birth rate and death rate, should be noted (Bailey 1984).

Economic carrying capacity (ECC2) is the maximum sustained yield of wildlife population. It should be known that the population level is lower than the ECC1. For a population growing logistically, its level is half of $K$ (Caughley 1976; Fryxell et al. 2014).

Birth rates are inputs to the population (Fryxell et al. 2014).

Death rates are losses to the population (Fryxell et al. 2014).

Wildlife management could be defined as the management of wild population in the ecological system; however, it may be limited for some researchers. Some scientists believe that many problems for wildlife management are related with humans. Therefore, popularization, education, park management, economics, law enforcement, and land evaluation are legal aspects of wildlife management, and they should be included in its definition (Fryxell et al. 2014).

Wildlife management means looking after a population. A population is a group of individuals belonging to the same species. When the population size becomes too small and near to extinct, conservation becomes urgent. In this condition, wildlife managers pay more attention to restoration activities. Wildlife management may be either controlled or supervised. A wildlife population could be managed in one of the following four ways: i) increase it; ii) decrease it; iii) harvest it for a sustainable yield; and iv) leave it as such but supervise it. Moreover, three decisions are needed: i) desired management goal; ii) appropriate management option; and iii) best action (Bailey 1984; Fryxell et al. 2014).

\section{Wildlife Conservation and wildlife management}

The aim of the wildlife conservation is to keep the wildlife surviving and reduce the trend of its extinction. Wildlife conservation depends on the kind of measures of wildlife management, such as habitat management (renovation, recover, rebuild etc.) and population management (number, sex ratio, age structure, pest control etc.). The wildlife management is the coexistence of humans and wildlife, or coexistence of humans and ecological system or species, including people using the wildlife resources efficiently, binding the utilizing and population optimization, preventing contagious diseases. Therefore, there are some common and overlapped points in both wildlife management and wildlife conservation, while difference is there at the same time.

The Convention on International Trade on Endangered Species of Wild Fauna and Flora (CITES) is a multifaceted deal, which intends to standardize the international wildlife trade and protect the threatened wildlife. The convention became effective on July 1, 1975 (Borsky et al. 2020). Nowadays, the agreement has been approved by 183 countries. To some extent, CITES provides security to about 5,800 animals and 30,000 plants; these are classified into three Appendices, based on the consequences of the wildlife' deal on their long-term sustainability. Appendix I consists of around 1,00o species, which are endangered with annihilation. The business for these species is allowed under special conditions. Appendix II includes around 34,500 species, which are not endangered with extinction if trade is not effectively monitored. Appendix III includes 200 species that are already protected by some countries, but the cooperation is needed from other countries to avoid the unsustainable exploitation (Borsky et al. 2020). For these species, group could be adjusted by their abundance and changed in different countries or even in the same country from year-to-year, according to the population size. Every trade flow should be documented for the specific species in the CITES lists or from a signatory country. CITES plays an important role to forbid illegal international trade. Moreover, Convention on Wetlands of Importance Especially as Waterfowl Habitat pays more attention to protect the 
waterfowls in the wetlands, which was implemented on December 21, 1975. Convention of Migratory Species or Bonn Convention could help to protect migratory wildlife on the land, in the ocean and sky, which was implemented on December 1, 1983. Convention on Biological Diversity could help to protect wild animals and plants, which was implemented on December 29, 1993. The above four conventions emphasize the international agreement to protect wildlife. Moreover, there are legal systems and acts to limit the citizens' behavior to manage and protect the wildlife and their habitats in the US and China, including Endangered Species Act (Noss et al. 1997; Malcom and Li 2015), Fish and Wildlife Coordination Act (Miller et al. 2011) in the US, and Wildlife Protection Act (2018) and Fisheries Act (2013) in China.

Louis Bernatchez emphasized on the important contributions to harvest management, stocking programs, definition of conservation units, recovery of threatened species, management of invasive species and forensic applications. In the fields of wildlife management, conservation and forensics (Figure 2), the Quebec government wildlife department greatly benefits from the maturity of genetics and genomics (Bourret et al. 2020).

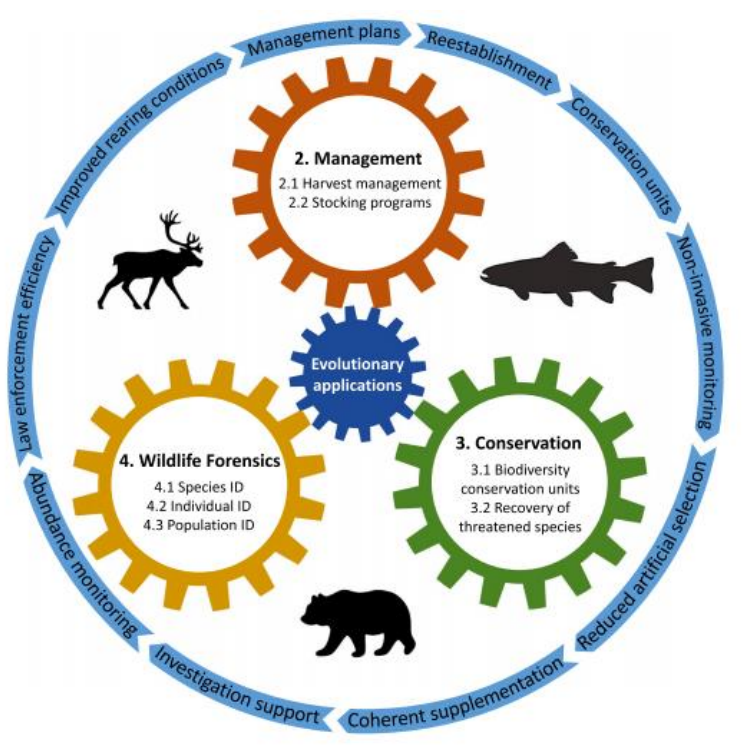

Figure 2: The Schematic themes (sections and subsections) showing the implementation outcomes set in motion by the integration of evolutionary applications (Bourret et al. 2020).

\section{Zoonotic diseases}

A zoonotic disease can be transmitted from vertebrate animals to humans or from humans to vertebrate animals in the nature (Rahman et al. 2020; WHO 2020a). The "Asia Pacific strategy for emerging diseases 2010" reported that about $61 \%$ of the existing human infections are zoonotic, and more than $70 \%$ came from wildlife, resulting from 1400 pathogens (Cleaveland et al. 2007; WHO 202ob). According to an estimate, there are between 650 ,000 and 840,000 known zoonotic pathogens that could have crossed the species barrier but have not yet done so (Perrings et al. 2018). Some major zoonotic diseases, such as Ebola, tuberculosis, bird flu and COVID19 have their origins in wildlife (Borsky et al. 2020). Different zoonotic diseases are caused by various pathogens, including bacteria, viruses, fungi, protozoa, parasites, and other pathogens. The emergence, distribution, and patterns of zoonotic diseases are greatly influenced by biological and abiotic factors. COVID-19 is a new zoonotic disease, and its pathogen seems to have been originated from bats. At present, the main issue is to effectively control the zoonosis. The implementation of One Health measures is highly recommended for this purpose (Rahman et al. 2020). Close contact between humans and animals is needed for the spread of some wildlife-origin infectious diseases, such as HIV, SARS, and COVID-19 (Wolfe et al. 2007; Borsky et al. 2020).

\section{Wildlife values}

In "Principles of wildlife management", the author described the following wildlife values (Bailey 1984):

Commercial value: The capitalized value of the income derived from selling or trading wild animals or their products (Bailey 1984). Some wildlife can be legally bred for consumption in wildlife farming like agricultural animals, such as tigers for bones, bears for bile, porcupines for meat, birds for pets, turtles and snakes for both food and pets, crocodiles for skin, frogs and shrimp for food etc. in some countries and territories (Rizzolo 2020).

Biological value: It is the contribution of wild animals to productive ecosystem. Wildl ife is a part of the complex biotic "machinery" of ecosystems that we rely on for food, water, fertilizer, and aesthetic and recreational values (Bailey 1984).

Recreational value: People derive benefits of pleasure, adventure, and enhanced physical and mental health from outdoor activities involving the pursuit or sometimes accidental enjoyment of wildlife (Bailey 1984).

Scientific, philosophical, and educational value: The scientific value of wildlife is the use of wild populations as experimental material for scientific study. Ecologists, ethologists, physiologists, pathologists, demographers, sociologists, and anthropologists have conducted studies on wild animals to extend their knowledge. The educational value of wildlife is realized from the use of wildlife examples in schools, at nature centers and park exhibits to enhance the understanding of people on the environment (Bailey 1984).

Aesthetic value: The use of wildlife and their habitats as objects of beauty or historical significance, and as they become part of literature, poetry, art, and music, are the most personal and variously conceived wildlife values (Bailey 1984).

Social value: People live in the community and wildlife can help us to get more benefits, not only for ourselves, but also for our neighbors (Bailey 1984). 
Negative value: The negative values of wildlife include the costs of wildlife damages to crops and other property and the costs of controlling these damages. Where these values can be expressed in cash, they should be subtracted from the total commercial and recreational value of the wildlife resources (Bailey 1984).

The total value of a wildlife resource is the sum of all the above positive values, minus the negative values. However, since the values are not commensurable (not measured in common units) and some are not even quantifiable, we cannot produce a single number to represent the total value of wildlife. This makes it difficult to compare the value of a new reservoir or strip mine with the value of the wildlife habitat that would be destroyed in developing these other resources. Since wildlife is a public owned resource, what total compensation is due the public when a mine is developed on public land and destroys a wildlife resource? One way to answer this question is to consider the total value of a wildlife resource as the cost necessary to replace it. Colorado has developed this method for calculating the costs of mitigating loss of wildlife habitat (Norman et al. 1975). Replacement costs include those for purchasing and developing new habitat and for improving existing habitat to increase its productivity (Bailey 1984). According to the survey in the surrounding areas of the Changqing National Nature Reserve in China (Hou et al. 2020), the cultural value of wildlife is significantly higher than that of the infrastructure and other natural landscape features.

\section{Wildlife strike risk}

The habitats for wildlife and humans are overlapped with the exploration of lands. Therefore, some animals would be hurt or killed by the vehicles, trains and ships, even airplanes. In the street, the dead body of skunk (Mephitis mephitis) and white-tailed deer were found in Washington State, and coyote (Proteles cristatus) was found on the street in Oregon State, USA in 2020. Some homeless dogs were killed on the streets in China in 2021. These animals were killed always by the cars and vehicles. Some marine wildlife even could be hurt by ships (Sèbe et al. 2020). In the airport, the birds are so often hit by the airplane in the world (Hu et al. 2020). How to reduce the risk and take some measures to protect the safety of humans and wildlife? It is a big problem for the scientists and governments. In recent years, traffic caused by bird strike events has increased along with the number of aircraft taking off and landing increased continuously. According to the statistics in "Bird Strike Aircraft Information Analysis Report" from the Civil Aviation Administration of China (CAAC), bird strike accidents increased from 326 in 2007 to 4618 in 2016 . The number of bird strikes in the US has increased from $185^{1}$ in 1990 to 13,668 in 2014, according to the data from the Federal Aviation Agency (FAA), USA (Lopez-Lago et al. 2017). The increasing bird strikes can cause aircraft accidents, which would bring the huge security risks and economic losses (Allan 200o). Bird strikes became an "A" aviation disaster in the International Federation of Aviation (Hu et al. 2020).
COVID-19, Global Climate Change and Pollution: Threatening Wildlife Management and the Public Health

COVID-19 has challenged the wildlife management and public health

The wildlife management becomes more and more popular as a research area for scientists in recent years, especially during COVID-19 epidemic time. COVID-19, coronavirus disease 2019, was found for the first time in China in December 2019, but in a short time, it became a serious infectious disease threatening all the people on the earth. There were over 185 million confirmed cases and over 4 million dead cases till July 9, 2021 (UTC/GMT+o8:0o) (Chinanews 2021). Human are suffering from the big disaster, and our life has totally changed after the new virus came to the world in December 2019. SARS-CoV-2, the pathogen of COVID-19, is the seventh coronavirus to infect humans, and other six coronaviruses included $229 \mathrm{E}-\mathrm{CoV}, \mathrm{NL}_{3}-\mathrm{CoV}, \mathrm{OC}_{43}-\mathrm{CoV}$, HKU1-CoV, SARS-CoV, and MERS-CoV (Hedman et al. 2021). At the same time, a large number of captive wildlife were killed for preventing the spread of COVID-19; this includes the domestic mink, which is the only known animal that can transmit SARS-CoV-2 to other minks and humans (Hedman et al. 2021). Denmark ordered to kill 17 million captive minks and UK ordered to kill all the minks to prevent COVID-19 transmission on November 2020, but the policy was opposed by some officials and businessmen (Shanxi Evening News 2020). The wildlife farming industry has been dramatically developed in the past decades in China (Anonymous 2017). According to "Report on the sustainable development strategy of wildlife farming industry in China", the annual output value was 133 billion RMB (about 20 billion dollars) for wildlife farming in 2016. International trade of wildlife is one of the important factors for zoonotic disease risk, as the zoonotic pathogens are traded as well (Borsky et al. 2020). The worst thing is that some captive animals were killed or burned to cut the spread of COVID-19, which caused huge economic losses for some businessmen and wildlife farming met the biggest obstruction during COVID-19 pandemic. All the governments in the world have already taken some strategies to recover the economy and people's daily life, but it is not so easy to achieve. The public health has been badely challenged due to COVID-19 pandemic. There has been always new variant of coronavirus that can appear anytime and anywhere in the world. The scientists in Harvard University hypothesized that COVID-19 would probably end in 2025, or it would coexist with humans forever, like flu (Liu 2021). Therefore, the wildlife management should be paid more attention than before in the current time. How to keep the wildlife and humans to live in harmony on the earth is the most important issue of the time.

Another disaster for public health is global climate change

The melt ponds were found on the Southern pole (Figure 3) and scientists recorded the highest temperature up to 
$20.75^{\circ} \mathrm{C}$ on February 9, 2020 (Anonymous 2020a). The researchers also found 2 million methane emission spots on the Northern pole on February 14, 2020 (New observations on Cosmology, February 16, 2020; Anonymous 2020b). The global warming would cause glacier melting and about more than 30\% polar bears could not survive in the next $35-40$ years, as shown in the report from International Union for Conservation of Nature (IUCN). Red snow appeared on the Southern pole on February 27, 2020 (Anonymous 2020c) and green snow was found there on May, 2020 (Woodyatt 2020). Glacial algae could be found on all continents, and most algae belong to Chlamydomonadales (Chlorophyta) and Zygnematales (Streptophyta). Other algal groups include euglenoids, cryptomonads, chrysophytes, dinoflagellates, and cyanobacteria. They can live under extreme conditions near $\mathrm{o}^{\circ} \mathrm{C}$, high or low irradiance levels, acidic $\mathrm{pH}$, low conductivity, and dryness after snow melts. These algae change the snow color to red, green, golden-brown, or purple-grey, and they are part of communities that include other bacteria, viruses, fungi, eukaryotes, and archaea.
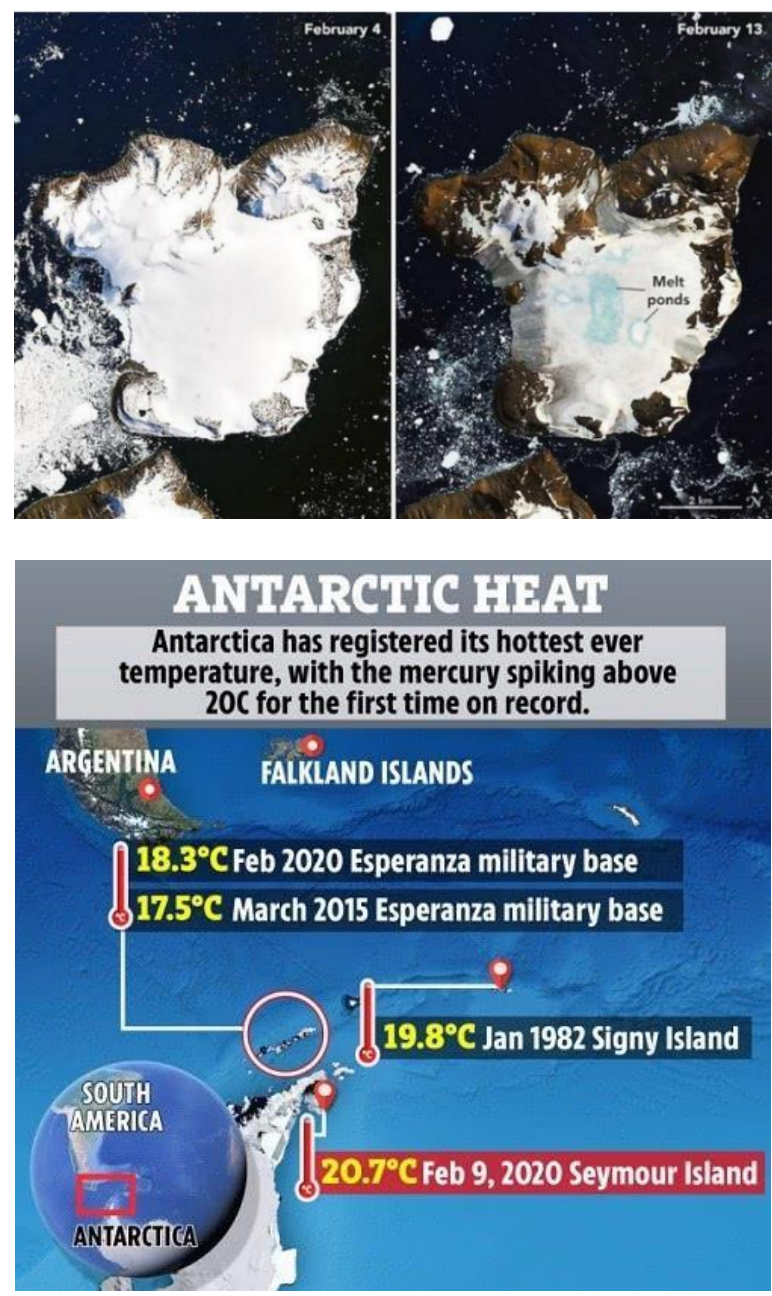

Figure 3: The southern pole was melting on February 2020, and $20.7^{\circ} \mathrm{C}$ hit the record (Anonymous 2020a).

They are one of the important components of the global biosphere and carbon and water cycles. Life cycles in the Chlamydomonas, Chloromonas and Chlainomonas include migration of flagellates in liquid water and formation of resistant cysts, many of which were classified as other algae (Figure 4). Glacial algae reduce albedo, accelerate the melting of snowpeaks and glaciers, and can be used to monitor climate change. Some selected strains of the above algae have potential for producing food or fuel products (Hoham and Remias 2020).

\section{Pollution is another big problem for wildlife}

The water system is polluted most seriously in the globe. The river, lake and ocean can be polluted by different kinds of algae, which can also cause death of some wildlife in the water, resultantly, the water surface looks like grassland with malodorous smelling. In China, pollution caused the harmful effects for some wildlife, especially for some waterfowls on December 2020. The reason either could be the algae in the water because not many terrestrial birds died at that time, or the temperature dramatically dropped. Some local birders found the egret, heron and colymbiformes died on the frozen surface in the river or lake in Weifang, a small city in Northeast of China. In the local botanic garden, the dead fish were seen floating on the water surface after melting of the frozen water. There should be some waterfowls swimming in the river in the city, but the pollution may drive them far away, only some terrestrial birds could have been found in the trees.

Harmful algal bloom events can be caused by rapid growth of photosynthesizing organisms in natural bodies of fresh and salt water (Roberts et al. 2020). These events can be intensified by nutrient pollutants (e.g., phosphorus) and warming waters or other climate changes (Wells et al. 2020), which have a negative effect on health of humans, animals and the environment (Backer et al. 2015; Adams et al. 2018). The public health concerns caused by harmful algal bloom events are centered on a subset of phytoplankton: diatoms, dinoflagellates, and cyanobacteria (or blue-green algae) in the US. One Health Harmful Algal Bloom System (OHHABS) was launched by Centers for Disease Control and Prevention (CDC) to inform efforts to prevent human and animal illnesses associated with harmful algal bloom in 2016 in the US. A total of 421 harmful algal bloom events, 389 cases of human illness, and 413 cases of animal illness were reported in 18 states during 2016-2018. Gastrointestinal diseases or generalized illness symptoms were the most frequently reported ( $>40 \%$ in human cases and $>50 \%$ in animal cases). However, other signs were also reported. The surveillance data from harmful algal bloom events could have been used to control and prevent the harmful algal bloom-related diseases (Roberts et al. 2020).

Algal bloom events have become a serious water pollution problem in freshwater ecosystems in the globe because harmful algae can gradually degenerate the selfpurification function of water and decrease the water quality (Paerl et al. 2011; Šulčius et al. 2017). In the past several decades, many scientists have studied the environmental factors of algal bloom outbreaks and 
decline (Paerl et al. 2011). High temperature, adequate light intensity and excessive exogenous nitrogen $(\mathrm{N})$ and phosphorous $(\mathrm{P})$ have been regarded as the three major abiotic factors (Metson et al. 2017).

Moreover, aquatic microorganisms play an important role in regulating water quality and composition of other organisms (Shao et al. 2014). The characterization of bacterial communities related with algal blooms in eutrophic lakes from China (Su et al. 2017) and the US (Berry et al. 2017), investigated by the 16S rRNA gene sequence method, have shown that algal blooms are formed by a biological disturbance in the bacterial communities of freshwater lake. In freshwater ecosystem, organic carbon, nitrogen and phosphorus cycling is greatly influenced by the microbial communities related with algal blooms (Zhang et al. 2018).

Furthermore, the used masks in the ocean killed and hurt so many wild animals during COVID-19 pandemic, which is one of the worst things to the wild environment. During the coronavirus pandemic, more and more disposable masks could be found anywhere, on the lands or in the water where people could arrive. According to a new report, an estimated 129 billion face masks and 65 billion plastic gloves were used every month for preventing the spread of COVID-19 on the globe (Sophie 2020).

\section{Conflict Between Human and Wildlife}

The conflict between human and wildlife usually occurs when the habitats for humans and animals overlap, and wild animals are increasingly adapting to urbanizing environments (Hadidian 2015). Nowadays, the problem is more serious than ever before because of the explosive growth of human population. According to an American official site, the following ways could be used to prevent human/wildlife conflict: no food for wildlife, secure storage for garbage, pets feeding in the house not outdoors to avoid attracting unwanted animals, fencing in the garden and preparation for learning about how to treat animals in the wild environment (McCarthy 2015).

The following cases will show seriousness of the conflict between human and wildlife in recent years.

Case I: On May 15, 2020, a 110-pound (about 5okg) male cougar was spotted by infrared camera in the backyard of a house near Mountain View Park in Ellensburg, Washington State, America and this big cat was killed by police in order to protect local citizens (Figure 5). For Washington Department of Fish and Wildlife agents, it was difficult to decide how to deal with the case. The officer explained that it was legal to take lethal measures for the citizens if they could demonstrate their personal safety and pets or livestock were at risk in front of some wild animals (Holappa 2020).

Case II: Kuzya, a Siberian tiger (Panthera tigris altaica/Putin's Tiger in Chinese) from Russia, was inspected in a Chinese reserve on October 9, 2014, according to GPS satellite data opened by a Russian scientist (Figure 6). Some Chinese researchers were
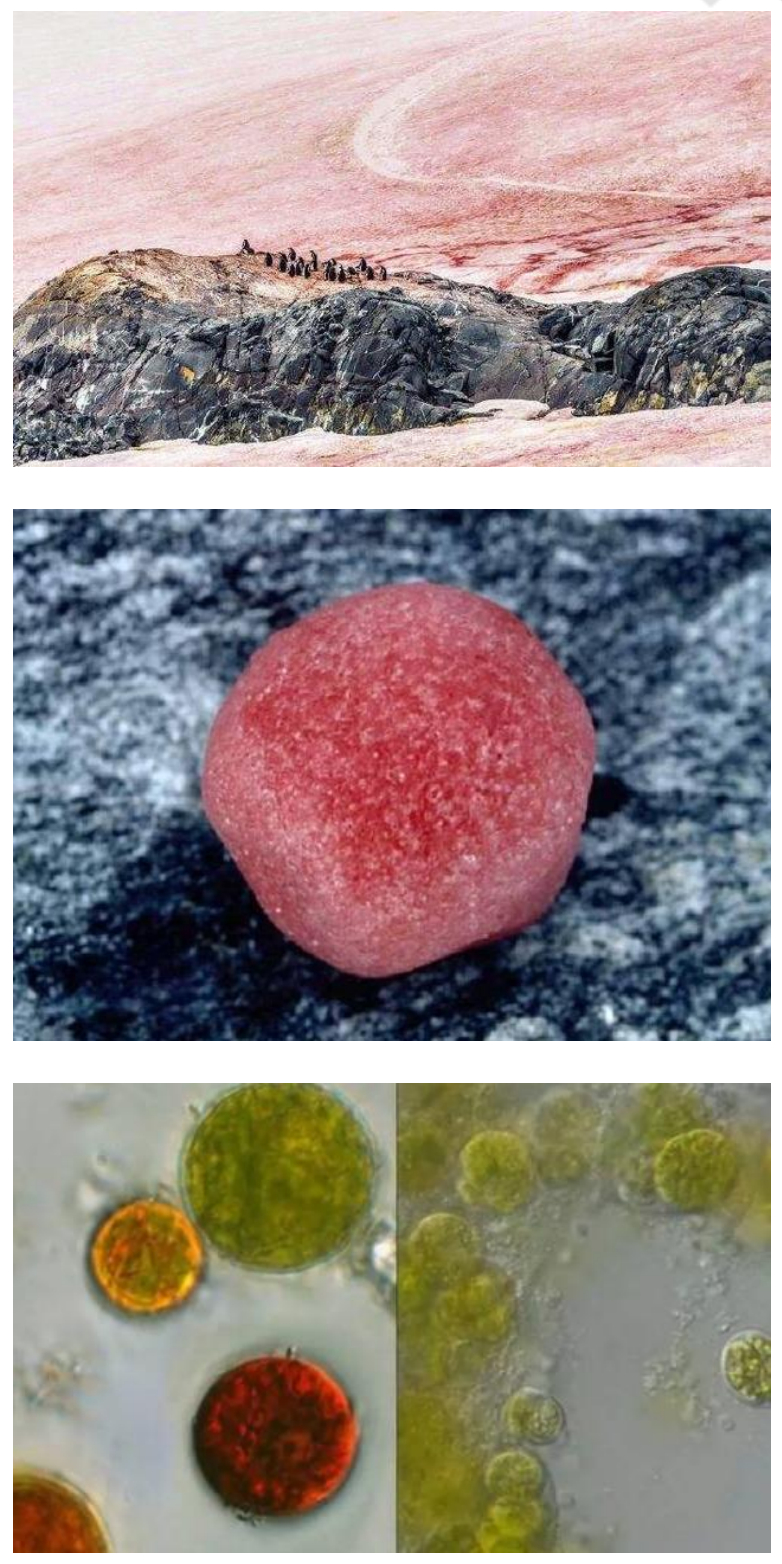

Figure 4: The microalgae (Chlamydomonas nivalis) caused the redlike snow on Southern pole on February 2020 (Anonymous 2021).

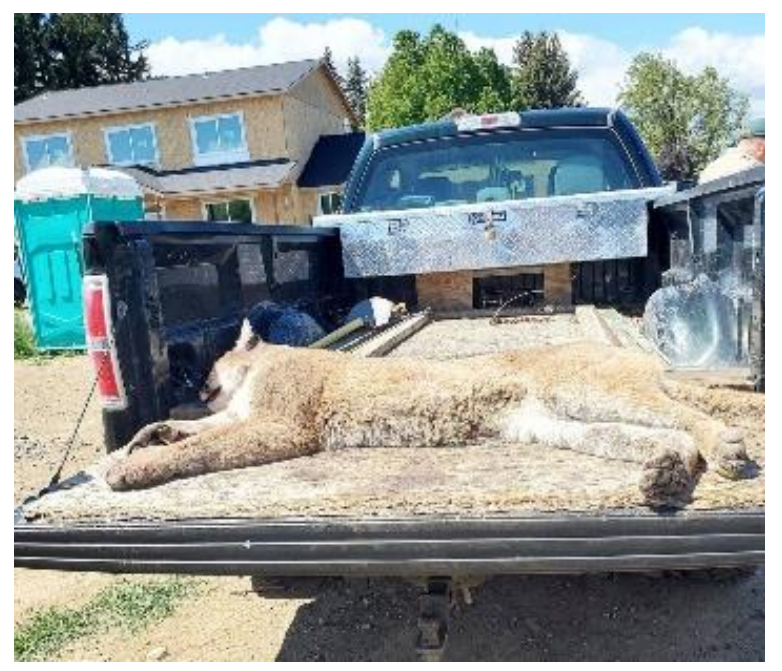

Figure 5: A 110-pound male cougar was killed because it was around a homeowner's house, near Mountain View Park in Ellensburg, WA, USA (Holappa 2020). 
requested by government to inspect the beast anytime, anywhere to protect local citizens and domestic animals near the natural reserve after the big cat entered Chinese land at that time. The Russian scientists contacted some Chinese organizations for protecting animals and asked them to treat the tiger better, keep it with no chicken or other meat, and avoid degrading its wild viability. Then Chinese local government began to launch a monitoring, early warning and protection mechanism to protect it. In the next two months, Chinese government paid more attention to this big cat because there were some trackers in Taipinggou Natural Reserve in Luobei county. According to the Director of the reserve, people felt excited about the finding of the first Siberian tiger there. But it was a huge challenge to China to protect the tiger back to Russia. In one month, the tiger hunted wild boars and deer in the reserve. Dr. Jiang Guangshun, a professor in Northeast Forestry University and the Executive Deputy Chief of the Field Research Center in the national forestry administration, said the Russian researchers had updated the new findings with the center. Moreover, the tiger was trained, especially before being released, and kept away from people. The wild boars and rabbits, as its food, could be easily found in the area where it was staying. Hair, feces and tracks left by the big cat were discovered in the areas where the beast was suspected to have travelled in the forestry area of the Lesser Xing'an Mountain in the northeastern province of Heilongjiang. Eventually, the tiger went back to Russia from Heilongjiang in China on December 7, 2014. Dr. Jiang Guangshun told the students in the class about Putin's Tiger in Northeast Forestry University in 2015. Chinese State Council required the specialists to report the activity of Putin's Tiger every day. There was a Chinese researcher in Russia at that time to transfer the data for the tiger from Russia to China and to make sure that both the tiger and local community were safe. The challenge could be regarded as a chance to evaluate the effectiveness of wildlife management in China. The good thing was that no one was hurt by the big animal, only some wildlife had been hunted, such as Chinese wild boars, roe deer (Capreolus pygargus), Northeastern hare (Lepus mandshuricus) etc. One Russian scientist said Kuzya found a good natural environment and sufficient food in the reserve. Now there are more than 500 wild Siberian tigers in the world. Chinese and Russian governments have agreed to save the tigers from extinction (Zhou 2014).

Case III: Fifteen Asian elephants left their habitat in Mengyangzi Nature reserve in Xishuangbanna, Dai autonomous prefecture, Yunnan province in April 2021 (Figure 7). They were found directed to the north of the province, just near the capital city Kunming about $120 \mathrm{~km}$ (Figure 8). Research workers tried to guide them to protect local residents and elephants themselves. Moreover, the elephants left their habitat last December to Mojiang county, and they traveled tens of Kilometers from Mojiang to Yuanjiang county during this April (Chinadaily 2021). The human-elephant conflict is the prominent problem in China. According to a study for human-elephant conflicts in 2011 to 2018 and questionnaire survey with 217 villagers, the number of elephants increased in the past 40 years, from 101 in 1976 to about 184-205 in 2016, and near 300 in 2021 (Su et al. 2020; Nangongxiaopang 2021). The main reason was the efficient work of Xishuangbanna nature reserve and improved awareness among local residents. However, the habitat loss and fragmentation for elephants may be the main reason to force them to leave the original habitat. The economic loss and threatens safety for local residents from elephants are so urgent that the efficient protection and management of Asian elephants are needed nowadays ( $\mathrm{Su}$ et al. 2020).

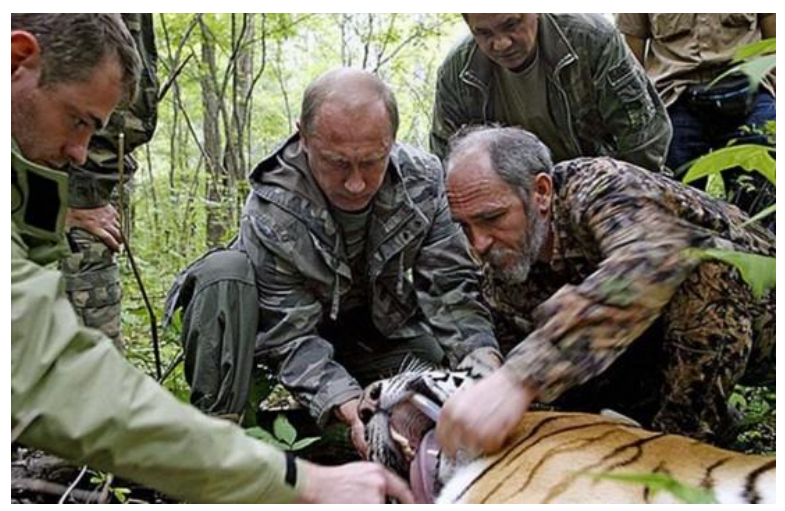

Figure 6: The tiger, named Kuzya, was one of three rare wild cats that Putin helped release into Russia's remote Amur region in eastern Siberia in May (Anonymous 2014a).

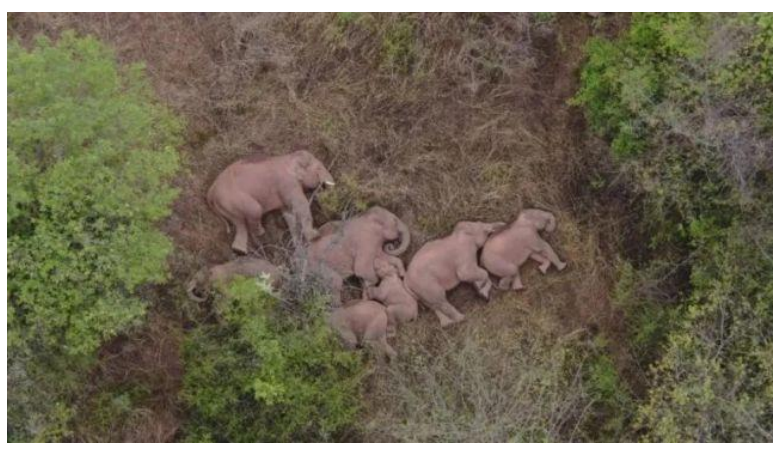

Figure 7: The Asian elephants are sleeping on the land near Kunming, Yunnan province in June 2021 (Shangfangwen 2021).

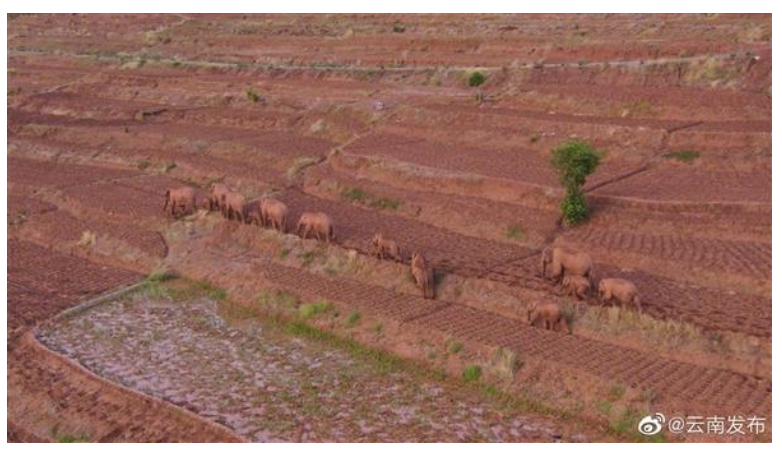

Figure 8: The Asian elephants are walking in the land near Kunming, Yunnan province in June 2021 (Shangfangwen 2021). 


\section{Wildlife Observation Practice in The United State}

The free terrestrial wildlife in the United State Observation Record

Why could the wildlife have chance to get more freedom in the US? According to the observation in Ellensburg, Washington (WA) and Redmond, Oregon (OR) during October 16, 2019 and November 7, 2020, the wild animals can easily move from one spot to others because there are not many fences and walls. For example, the buildings in Central Washington University (CWU) and houses of local citizens in Ellensburg are standing there, only lawns are regarded as boundary, with almost no barrier for the wildlife in the natural environment. Moreover, human interference is rare in the local parks and neighborhood. And the air quality is always very clean during the whole year, except for the wildfire time in 2020.

The Mallards were found in the cricks near CWU campus in the whole year. They could prey, swim and rest in the small rivers and fly to the near lakes or rivers to get food during winter when the local water surface was frozen. Even they could eat some ice and nuts under the trees and on the lawn in winter in front of Science Building in CWU. The California Quails could hide themselves in the bushes and take their several chicks to find fresh and tender grass and lie on the ground in the sunny days in summer. Mallards, California Quails and Doves could be found walking across the streets when the drivers would stop to wait for them first. Sometimes Mallards and doves stayed in the middle of streets, not hurry to go, then some drivers probably started engine and the birds would fly away immediately. There were about twenty crowns croaked in the neighbor's yard on a summer evening 2020, an owl standing on the pine tree. Then the noise attracted an eagle and a crown was prayed by the eagle. At last, other crowns flew away from the yard. Robin was found on the lawn to dig earthworms too and it was aggressive. It could drive other small birds away from the lawn, except for magpie. Magpie could still stay on the lawn, while robin showed aggressiveness, because magpie could dig earthworms and it is bigger than robin. Around 10 wild turkeys were found near a forest in Kittitas county, WA. Hummingbirds were attracted to get food by some feeders near a mountain in Redmond, OR. It was so small like a black spot when birding location was a little far near the hill, and it flew up and down like a helicopter in Ellensburg, WA. A Wilson's snipe was found after rain near the grassland for feeding cattle, some temporary cricks were also there. Bald eagle could be found in the sky near the Yakima River and in Irene Rinehart Riverfront Park. Another eagle stood under a pine tree on the snowy lawn in front of the library of CWU in 2019 winter, frightening a crown away. Swallow could be found in a grassland in summer. Woodpecker was always in the park or on the big tree. Blue jay was spotted on the lawn and in the mountain. Red-winged blackbird could be found in the trees near a trail. Falcon could be found in the suburb. Several seagulls were found in the sky near Columbia river in summer. The Canada geese could live the whole year in Carey Lake in Irene Rinehart Riverfront Park, taking the branches from beavers' cutting to build nests. They could migrate in summer, west to east in the morning and east to west in the evening located by the sun from July to September. Moreover, so many small birds could not be recognized one by one. All the birds live in the peaceful and quiet environment in a small city, with no more than 20,00o people there.

The wild mammals were not easy to be found in the natural environment. Only white-tailed deer appeared often in the golf course turf in Ellensburg, WA. One squirrel was found in the turfgrass in Redmond, OR. The beavers left imprints by strong teeth on the tree trunks and dragged them and small branches to build dams to be used as home and get food for families in Carey Lake, Irene Rinehart Riverfront Park. The skunk's dead body was found on the street in summer, dying of roadkill. Both coyote and white-tailed deer were killed by the vehicles. The chipmunk was found on the top of the local mountain. The rabbit and hare could be seen near a trail and in a small park. In winter, there were some imprints on the snowy lawn in the backyard and in Irene Rinehart Riverfront Park. The foot imprints of weasel (Mustela sibirica), raccoon (Procyon lotor), American black bear, deer, rabbit and hare, wild cats could also be seen. The cave's imprints of rodents could be found on the lawn in the backyard and park. They could be moles or other rodents.

The reptiles and amphibians were not easily observed and recorded. But one small snake appeared on the trail after rain in summer. The voice of some frogs could be heard in Irene Rinehart Riverfront Park or in the ponds in Ellensburg, and some frogs could be heard in the pond in Redmond, OR.

Why the wildlife could be so free in the USA? Why could they keep the natural environment so well? How can other countries get some inspire and wisdom from the wildlife management in the USA? All this is due to the fact that the constitution and acts are very strong and strict in the USA (Treves et al. 2017). There are over 170 Federal laws that regulate environmental activities which may affect wildlife, such as Lacey Act of 1900, Migratory Bird Hunting Stamp Tax Act of 1934, Pittman-Robertson Act of 1937, Fish and Wildlife Coordination Act of 1958, National Environmental Policy Act of 1969 (Fairbrother 2009) and Endangered Species Act of 1973 (Carroll et al. 2010) etc. The wildlife is protected by the laws and principles. Even in the hunting season, citizens can hunt only some wild animals if they have legal hunting licenses, but there are strict rules for hunting (Messinger et al. 2019). All the people in the USA have consciousness to protect the wildlife in their mind, which is necessary in the world to keep our natural resources - wildlife and helpful to decrease the trend of extinction for some endangered species (Treves et al. 2017). The suggestion could be developing the acts and popularizing laws and principles among the communities in the underdeveloped countries, and all the governments need cooperate in the human's common assets - wildlife. 
An observation record on Canada geese in the United State

The Canada goose (Branta canadensis) is the largest wild goose in the world, with the subspecies "giant Canada goose" having specimens weighing over $9 \mathrm{~kg}$. However, most Canada geese weigh between 2.3 and $6.4 \mathrm{~kg}$ (5 and 14 pounds), with females weighing slightly less than males. Canada goose measures from $76 \mathrm{~cm}$ to $114 \mathrm{~cm}$ in length and has a wingspan between $127 \mathrm{~cm}$ and $190 \mathrm{~cm}$. The Canada goose can be distinguished from other species of geese by its distinguished black neck and head, by a striking white "chinstrap" on the neck, and by a lightly colored breast and a brown back (Figure 9). Like other geese, they have an elongated neck, as well as webbed feet, and both these adaptations make them quite agile in the water when they are going after food.

The observational spot on Canada geese was near Central Washington University and Yakima River in Ellensburg, Washington State in the USA. Observations were made during 18 mornings and 12 evenings from July 27 to

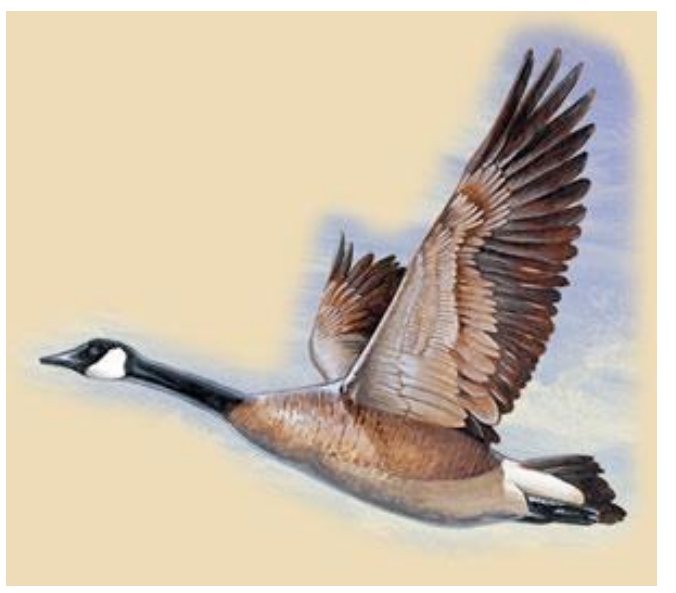

September 18. The date, time, weather, and all observations were recorded to account for differences in environmental conditions. Data collected included: the number of geese present and the flock activities and behaviors. OPPO R17 application was used to take photographs and video recordings of the geese were taken to document the observational data.

In Ellensburg, the Canada geese were found throughout the year according to the map of Canada goose distribution (Figure 10). There are more than 70 observers' data of Canada geese in Ellensburg Valley from September 1998 to April 2020 on the current eBird website (Table 3). The most observation spots are near the I-9o highway and Yakima River (Figure 11). In this report, the records for Canada geese were found in the Carey Lake at Irene Rinehart Riverfront Park near Yakima River in winter (Figure 12 and 13), while they were found in sky on Abel place during summer (Figure 14) and on the grassland near John Wayne Trail in autumn (Figure 15). The focus was the movement behavior from July 27 to September 18 in this report.

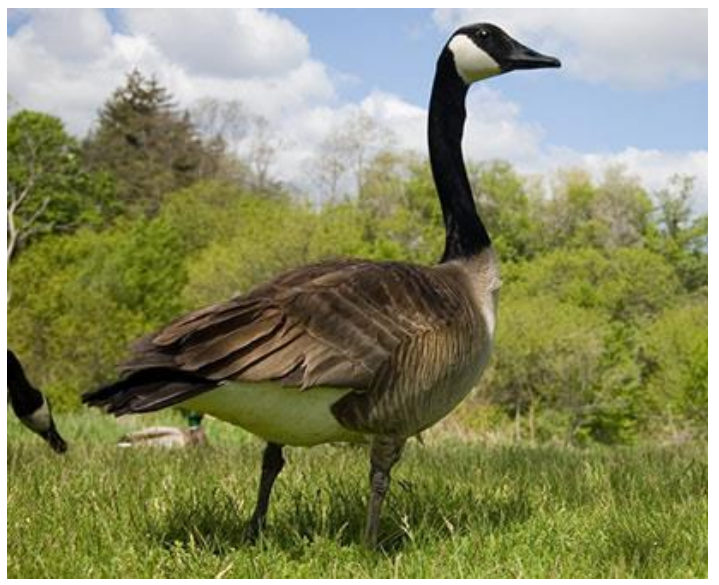

Figure 9: The superficial character of Canada goose. https://forum.americanexpedition.us/canada-goose-informationfacts-photos-and-artwork

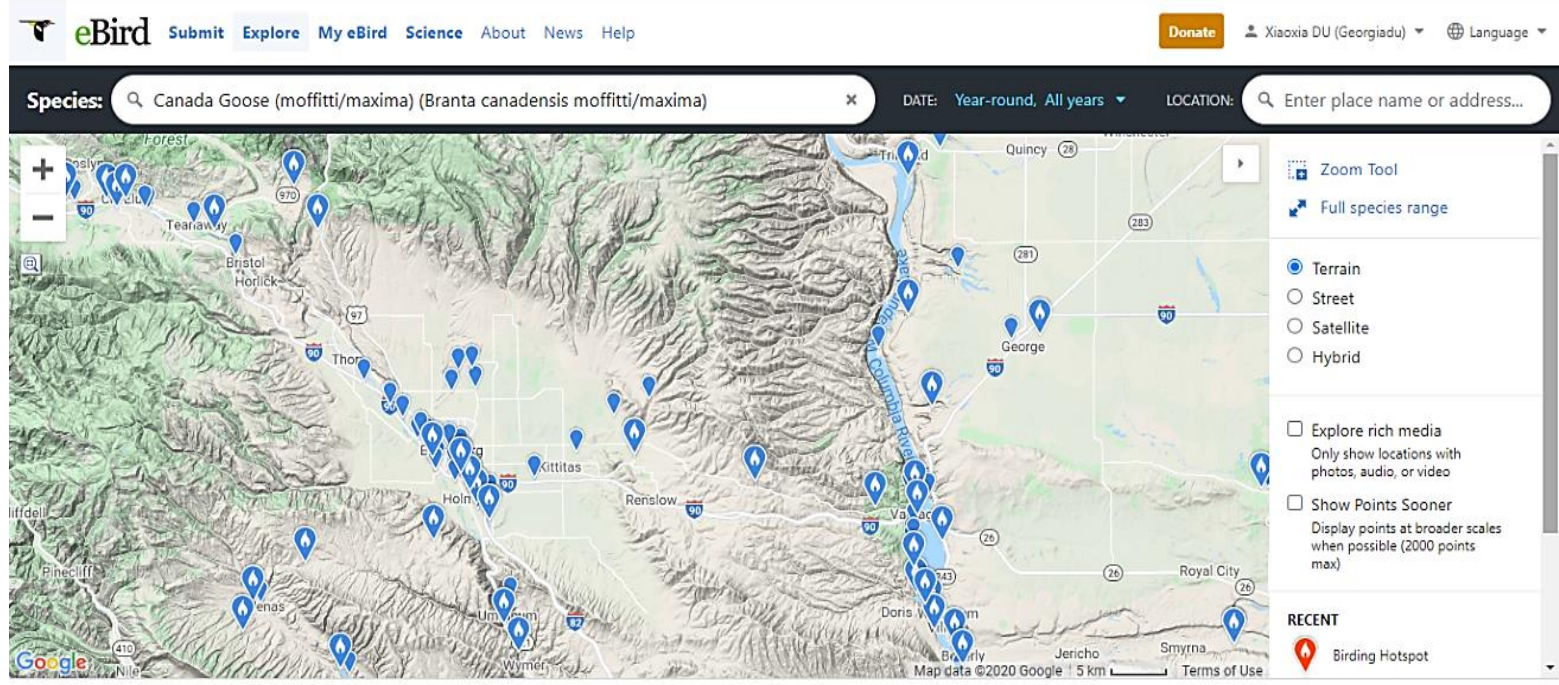

Figure 10: Spots of Canada geese in Ellensburg Valley on the current eBird website from September 1998 to April 2020 (https://ebird.org/map/cangoo4?neg=true\&env.minX=\&env.minY=\&env.maxX=\&env.maxY=\&zh=false\&gp=false\&ev=Z\& $\mathrm{mr}=1-12 \& \mathrm{bmo}=1 \&$ emo $=12 \& \mathrm{yr}=\mathrm{all} \& \mathrm{byr}=1900 \&$ eyr $=2020)$. 


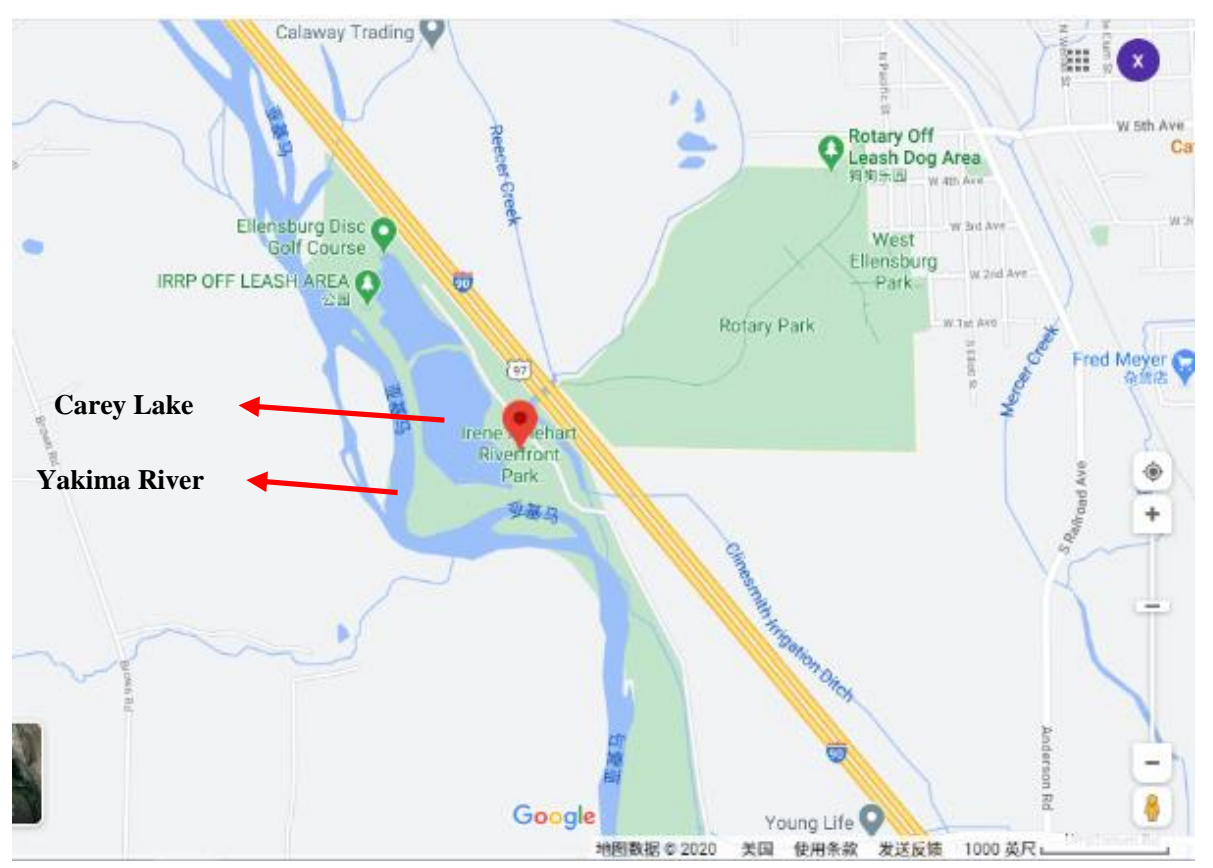

Figure 11: Carey Lake at Irene Rinehart Riverfront Park near Yakima River in Washington State in the USA in Google map.

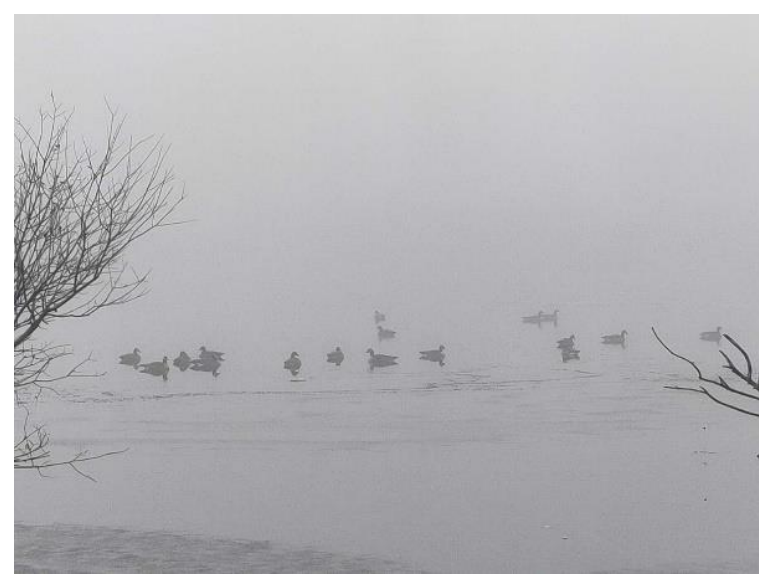

Figure 12: Canada geese are in Carey Lake at Irene Rinehart Riverfront Park in winter. Date/time: 15:09:05, Dec 8, 2019 Location: Carey Lake at Irene Rinehart Riverfront Park, Ellensburg.

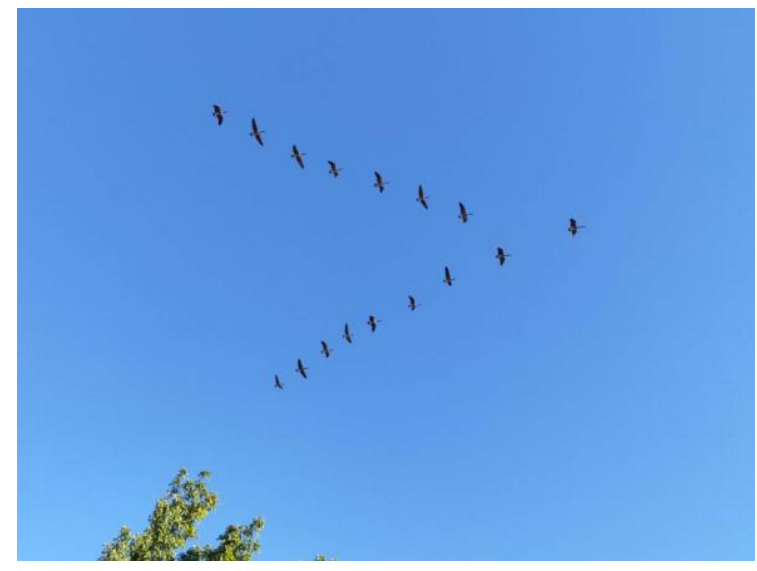

Figure 14: Canada geese in flock in V-shaped in summer. Date/time: 08:10:30 Aug 19, 2020. Location: Abel Place, Ellensburg.

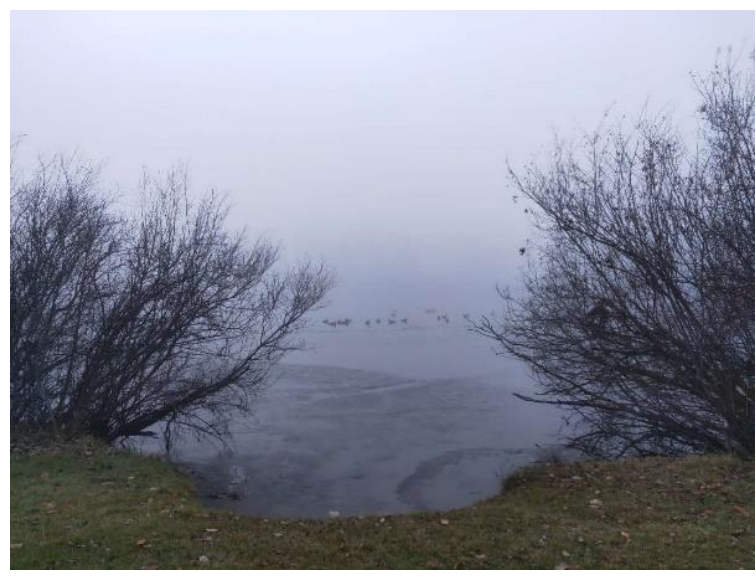

Figure 13: Canada geese are in Carey Lake at Irene Rinehart Riverfront Park in winter. Date/time: 15:09:01, Dec 8, 2019 Location: Carey Lake at Irene Rinehart Riverfront Park, Ellensburg.

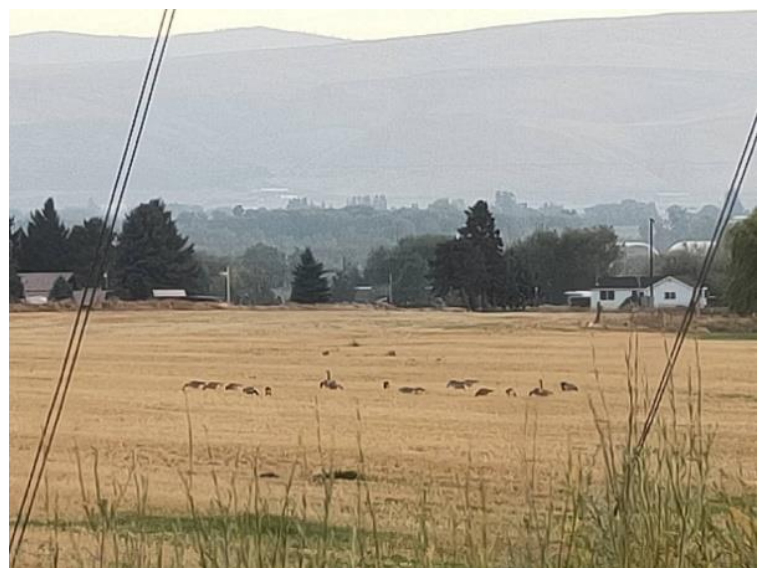

Figure 15: Canada geese on the grassland in fall. Date/time: 18:26:07 Oct 4, 2020. Location: John Wayne Trail, Ellensburg. 
The Canada geese showed a relatively regular movement schedules in the morning and evening during summer and autumn in 2020. The Canada geese were observed from July 27, 2020 to September 18, 2020 in Ellensburg. They didn't show the regular movement schedule after September 18, 2020 (Table 4).

The Canada geese can fly in the morning and in the evening during the observation time. But they can show different kinds of groups and different characters during the movement. In the morning, they began to group and fly from the Carey Lake (west) to sunrise location (east), and they migrated from east to west in the evening. The population size for each flock varied from 2 to 39, occasionally single goose, but most time it was around 10 to 30. In the morning, the movement time lasts longer than evening from the beginning to the end. The movement time was about 7:50 am in the morning, while 5:30 pm in the evening, occasionally they were found in the sky on other times, such as 6:00 am and 3:00 pm (Table 5).

\section{Morning movement behavior}

Most of the time, the Canada geese moved from west to east, but sometimes toward north in the morning from July 27, 2020 to September 18, 2020. Normally, their staring time and ending time could last 5-43 minutes in the morning. The movement time was earlier on 7:50 am (August 3, August 4, 2020, when highest temperature was $32-33^{\circ} \mathrm{C}$ ) in the hot days, and later until 9:36 am (September 18, 2020, when highest temperature was near $24^{\circ} \mathrm{C}$ ) in the cool days. At the beginning of grouping, the shape of their flocks looked like a straight line (August 18, 2020), and sometimes they changed the shape gradually, but sometimes they kept the straight line for several minutes, and then changed the formation. During this formation, each goose found its own position in the flock and cooperated with other individuals to go forward. The largest population size was about 800 on August 19, 2020, about 600 on August 17, 2020 and 56o on August 18, 2020 (The highest temperature was higher than other days, up to $34-38^{\circ} \mathrm{C}$ ). The mountain fire caused pollution in Ellensburg from September 15, 2020 to September 18, 2020. The formation of folks was different from other days in the smoking condition (Figure 16), more geese were together, and sometimes shaped like double "V" shaped (Figure 17). The smallest population size was about 20-30 on August 3, 2020 and August 11, 2020 (The highest temperature was near $32^{\circ} \mathrm{C}$ ).

\section{Evening movement behavior}

The Canada geese moved from east to west in the evening from July 27, 2020 to September 18, 2020. The movement time was about 5:30 pm on the hot days on August 8, 2020 and August 31, 2020 (The highest temperature was up to $30^{\circ} \mathrm{C}$ ), and about 7:00 pm on the cool day on August 12, 2020 (The highest temperature was near $26^{\circ} \mathrm{C}$ ). But the geese movement schedule was much earlier than other days on August 28, 2020 because the lowest temperature dropped to $9^{\circ} \mathrm{C}$, and lower than the lowest temperature, higher than $11^{\circ} \mathrm{C}$ on other days. There was a special day on August 13, 2020, when the lowest temperature was near $6^{\circ} \mathrm{C}$, the movement time didn't change too much, but the population size was about 270. Therefore, the population size in the evening was bigger when the temperature was lower on August 28, 2020, while it was smaller when the temperature was higher on August 8, 2020.

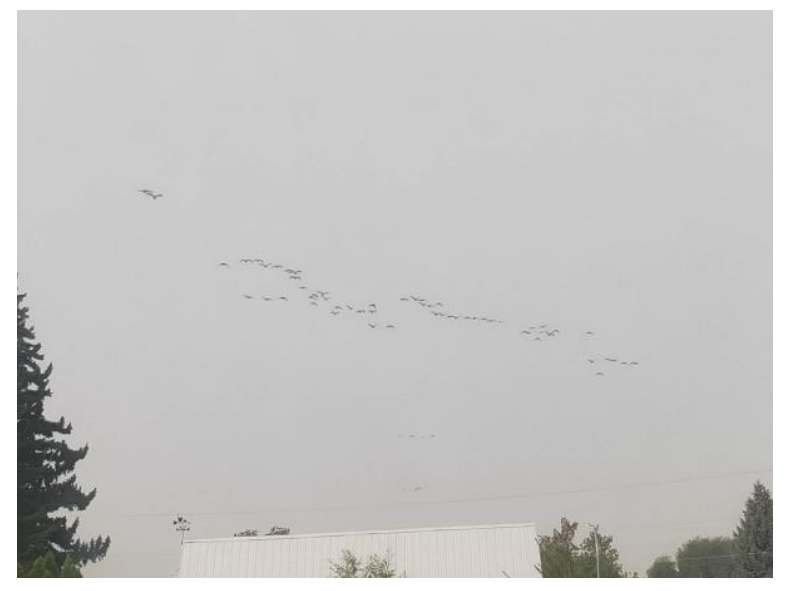

Figure 16: Some flocks of Canada geese together to go forward in smoking condition in the morning. Date/time: 09:36:39 Sep 18, 2020. Location: Abel Place, Ellensburg.

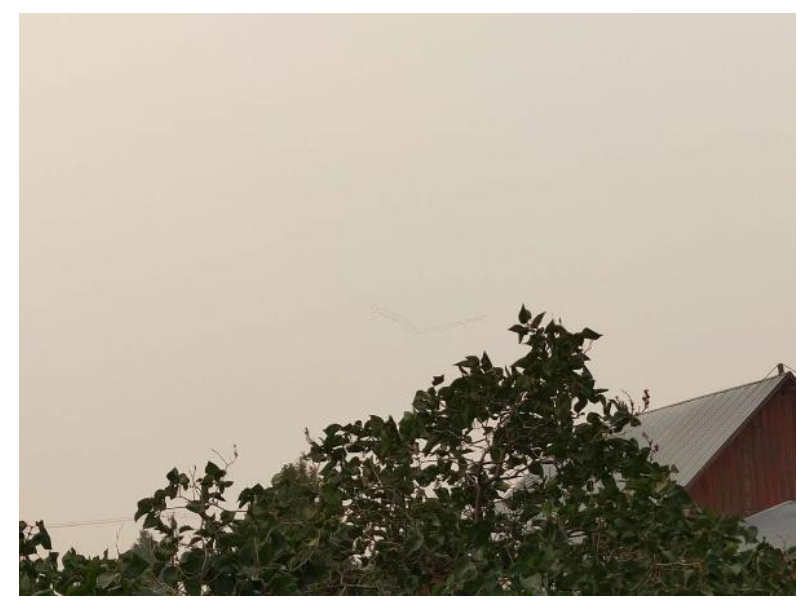

Figure 17: The Canada geese in folk shaped like double "V" in smoking condition in the afternoon. Date/time: 15:39:22 Sep 15, 2020. Location: Abel Place, Ellensburg.

It was not easy to identify whether their movement was short or long according to observation. This was because the movement time was in summer, and it was different from autumn and spring migration. Some researchers found that Canada geese had movement in summer. The short-distance movement of Canada geese migration can be seen from September to the beginning of November (Landys et al. 2004). The late summer movements by giant Canada geese were related with the September hunting season (Dieter et al. 2010). The movement schedule of Canada geese can change with the temperature, so there is possible correlation between movement in summer and temperature. The data was 
insufficient to analyze statistically, but some data showed the regular patterns.

The sun and star may help Canada goose to locate the movement

The sun may help Canada geese to locate the movement direction. This is because their movement went toward sunrise direction from west to east in the morning, and toward sunset direction from east to west in the evening. There was a famous experiment published in New York Times on September 28, 1993, titled "Migrating birds set compasses by sunlight and stars". Dr. Kenneth P. Able and Mary A. Able, both in the State University of New York at Albany, showed evidence that Savannah sparrows, migrating between the Northeast and the Deep South or Mexico, could see polarization pattern in the daylight, but also use the orientation patterns as a navigation aid for calibrating their magnetic directional sense. The birds were not influenced by the position of the sun, but by the polarization direction of sunlight scattered by the atmosphere. Migratory birds could use a magnetic compass in their eyes for navigation. Its basic sensory mechanisms have long remained elusive, but now researchers have revealed exactly where in the eye, the birds' control center for navigation is situated (Anonymous 2018).

The movement behavior of Canada goose may find suitable habitats in summer in Ellensburg, WA, United States

The moment behavior of Canada goose was observed in summer and autumn in Ellensburg, and published in a paper, titled "Canada Goose-Early Summer Migration" (Martin and Foote-Martin 2018). The first movement of molt migrants of Canada geese was in the beginning of June, along with other migrants, and continued for next two weeks or so in Wisconsin. The non-breeders started to make flock and inviting others to prepare for their northern flight, where they could replenish feathers. At that time, nearly all the young ones had hatched and it was most likely to allow failed breeders to join the flocks. The only clutches that were still to hatch in the southern United States were making re-nesting efforts and some of the early hatched young ones were nearly half grown-up. When geese are traveling, they mostly flew a few hundred feet high, but the flocks present at higher altitude and toward north were a sign of the molt migration. Michigan's Waterfowl Biologists discovered that the geese migrated over 600 miles to the place around James Bay. They also discovered that most non-breeding geese in the countryside migrated, whilst a quarter of their "park" geese took part in the migration.

The geese were "giant" subspecies (Brania Canadensis maxima). In the 180o's, the giant goose was hunted all the year, and eggs and young birds were also taken for food. By the 190os, there were almost certainly no nesting giant Canada geese in Wisconsin. In spite of this, they could be found in game breeders' hands and the breeders supplied the source for the DNR reintroductions in the 196os and 1970s. Mark assisted the pinioned adults at Crex Meadows State Wildlife Area in 1970 from their winter-pens to summer-pens so that their offspring would fly out of the summer-pens to build a population. Canada geese nested during 1996 for the first time at Goose Pond. The Waterfowl Biologists in Wisconsin Department Natural Resources (WIDNR) anticipated in 2017 that the giant Canada goose population could be 158,0oo (Martin and Foote-Martin 2018). Until reaching the age of two years, Canada geese would not start nesting. There must be a thrilling time for a-year-old birds led by failed breeders to north for a summer vacation in the land of the polar bears.

The movement behavior of Canada goose may have special function in summer in Ellensburg, WA, USA. It is possible that Canada goose moved to the north or east direction in summer hot days in order to be away from the hot weather, searching for suitable habitats. It is evident that the movement population of Canada goose in cool days was less than that in hot days. But the data is not enough to analyze the relationship between temperature and their schedules in the morning and in the evening. Further observation could be conducted to find the rule of migration in summer.

The summer movement may help Canada goose from being hunted

The late summer movements by giant Canada geese were related with the September hunting season (Dieter et al. 2010). The population size is growing substantially in recent years, a September hunting season was implemented in more than 40 states in the USA to control the number of Canada goose, which may change their movement behavior. Sometimes there will have a conflict to get benefits between wildlife and humans. It is not easy to manage wildlife without human's interference.

For example, the population size for Canada goose declined by early 2oth century, and almost extincted in the 1950s (Hanson 1997), but Northern Prairie Wildlife Research Center and center's Canada goose production and restoration program protected the species between 1964 and 1981. Then 64 pens with 64 breeding pairs of screened, high-quality birds were used to conduct the project, and the population size of Canada geese was raised to more than 6o,ooo in North Dakota (Anonymous 2013; Figure 18). Their number recovered in most ranges with improved game laws and habitat recreation and preservation programs. But later, their populations in some places grew substantially. Therefore, many people regarded them as pests for their droppings, noise, and confrontational behavior. This problem was partially due to lack of natural predators and an abundance of safe food sources in man-made bodies of water (Anonymous 2015), such as golf courses, public parks and beaches, or planned communities. Canada geese were frequently a yeararound feature of urban environments due to the partly interbreeding of various migratory subspecies with the 
Table 3: Canada goose records on Ellensburg valley in eBird website from September 1998 to April 2020 (Anonymous 2020d)

\begin{tabular}{|c|c|c|c|c|}
\hline No. & Numbers & Date & Address & Observer \\
\hline 1 & 5 & Sep 1, 1998 & Vantage Area, Kittitas County & Steven Mlodinow \\
\hline 2 & 10 & May 20, 2010 & Woodhouse Loop & Caleb Davidson \\
\hline 3 & 2 & Sep 18, 2010 & Vantage Area, Kittitas County & Steven Mlodinow \\
\hline 4 & 25 & Feb 2, 2013 & Irene Rinehart Riverfront Park & KAS trips, Eric Heisey \\
\hline 5 & 2 & Mar 2, 2013 & Ellensburg & Eric Heisey \\
\hline 6 & 6 & May 31, 2013 & Kittitas County - Parke Creek Road & Bradley Waggoner \\
\hline 7 & 21 & Nov 29, 2013 & KitC-I-9o & Jon Isacoff \\
\hline 8 & 5 & Jan 26, 2014 & Irene Rinehart Riverfront Park & Shep Thorp \\
\hline 9 & 4 & Jun 1, 2014 & Bettas Rd & Bradley Waggoner \\
\hline 10 & 60 & Sep 6, 2014 & Ellensburg - I-9o corridor & Michael Shepard \\
\hline 11 & 30 & Nov 16, 2014 & Bar 14 Pond & Jeanelle Richardson \\
\hline 12 & 55 & Nov 26, 2014 & KitC-Ellensberg & Jon Isacoff \\
\hline 13 & 22 & Mar 24, 2015 & Vantage Hwy at Parke Creek & $\begin{array}{l}\text { Pamela Myers, John Grettenberger, } \\
\text { Teri Martine, Jon. Anderson }\end{array}$ \\
\hline 14 & 15 & Mar 29, 2015 & Kittitas Valley--Tjossem Pond & Andy Stepniewski, Eric Heisey \\
\hline 15 & 60 & Mar 29, 2015 & Kittitas Valley--Tjossem Pond & $\begin{array}{l}\text { Jon. Anderson, Teri Martine, John } \\
\text { Grettenberger, Pamela Myers }\end{array}$ \\
\hline 16 & 2 & May 15, 2015 & KitC-Ellensberg & Jon Isacoff \\
\hline 17 & 5 & Apr 9, 2016 & Irene Rinehart Waterfront Park & $\begin{array}{l}\text { Carol Smith, Faye Hands, Diane } \\
\text { Yorgason-Quinn, Laurel Parshall }\end{array}$ \\
\hline 18 & 6 & Apr 30, 2016 & Kittitas Valley--Tjossem Pond & $\begin{array}{l}\text { Barbara Petersen, Marissa Benavente, } \\
\text { Jim Flynn }\end{array}$ \\
\hline 19 & 9 & May 1,2016 & Kittitas Valley--Tjossem Pond & Eric Heisey \\
\hline 20 & 15 & May 26, 2016 & Kittitas County - Parke Creek Road & Bradley Waggoner \\
\hline 21 & 2 & May 26, 2016 & Kittitas Valley--Tjossem Pond & Bradley Waggoner \\
\hline 22 & 8 & May 26, 2016 & Bar 14 Pond & Bradley Waggoner \\
\hline 23 & 36 & Sep 1, 2016 & Ellensburg - general location & Michael Shepard \\
\hline 24 & 175 & Nov 12, 2016 & sorenson pond & steve giles \\
\hline 25 & 7 & Nov 13, 2016 & Tipton rd & steve giles \\
\hline 26 & 25 & Nov 13, 2016 & hungry junction rd kittitas co & steve giles \\
\hline 27 & 290 & Dec 3, 2016 & sorenson pond & steve giles \\
\hline 28 & 33 & Dec 3, 2016 & Bar 14 Pond & steve giles \\
\hline 29 & 35 & Apr 2, 2017 & Kittitas Valley--Tjossem Pond & Adrian Lee \\
\hline 30 & 3 & Apr 12, 2017 & Ellensburg -- EconoLodge & Craig Tumer \\
\hline 31 & 7 & May 28, 2017 & Parke Creek Road & Guy McWethy, Carol Riddell \\
\hline 32 & 93 & Oct 23, 2017 & Kittitas Valley--Tjossem Pond & Carol Riddell \\
\hline 33 & 150 & Nov 16, 2017 & Number 6 Gravel Ponds & Carol Riddell \\
\hline 34 & 100 & Nov 16, 2017 & Bar 14 Pond & Carol Riddell \\
\hline 35 & 115 & Jan 12, 2018 & I-9o at Umptanum Road & Jon. Anderson \\
\hline 36 & 25 & Jan 12, 2018 & Yakima River ponds I-9o & Jon Anderson \\
\hline 37 & 42 & Mar 10, 2018 & 1304 S Canyon Rd, Ellensburg & Sheryl Bayles \\
\hline 38 & 2 & Apr 5, 2018 & $\begin{array}{l}1138-1188 \text { Tipton Rd, Ellensburg (47.0586- } \\
120.5221 \text { ) }\end{array}$ & Sheryl Bayles \\
\hline 39 & 15 & Apr 22, 2018 & Bar 14 Pond & Jaimo Goff, Eric Heisey \\
\hline 40 & 30 & May 14, 2018 & Number 6 Gravel Ponds & Walter Szeliga \\
\hline 41 & 55 & Oct 21,2018 & Number 6 Gravel Ponds & Carol Riddell \\
\hline 42 & 150 & Oct 21, 2018 & Kittitas Valley--Tjossem Pond & Carol Riddell \\
\hline 43 & 6 & Jan 26,2019 & $\begin{array}{l}4761 \text { Number } 6 \text { Road, Ellensburg, } \\
\text { Washington, US (46.957, -120.501) }\end{array}$ & Terry Carkner \\
\hline 44 & 9 & Feb 2, 2019 & Irene Rhinehart Riverfront Park & Terry Carkner \\
\hline 45 & 4 & Mar 29, 2019 & roadside ponds & Joshua Glant \\
\hline 46 & 8 & Apr 12, 2019 & Woodhouse Loop & Dan Waggoner \\
\hline 47 & 16 & Apr 12, 2019 & Kittitas Valley-Tjossem Pond & Dan Waggoner \\
\hline 48 & 7 & Apr 15, 2019 & Kittitas Valley-Tjossem Pond & David Poortinga \\
\hline 49 & 12 & May 17, 2019 & Woodhouse Loop & Bradley Waggoner \\
\hline 50 & 32 & May 17, 2019 & $\begin{array}{l}\text { Kittitas County - NE Ellensburg } \\
\text { pastureland }\end{array}$ & Bradley Waggoner \\
\hline 51 & 6 & May 17, 2019 & Kittitas--Parke Creek Road & Bradley Waggoner \\
\hline 52 & 2 & May 17, 2019 & Kittitas I5 Ponds & Bradley Waggoner \\
\hline 53 & 2 & May 25, 2019 & Ellensburg region & Adrian Lee \\
\hline 54 & 45 & Jul 25, 2019 & I-9o Kittitas Co & Adrian Lee \\
\hline 55 & 10 & Jul 26, 2019 & I-9o Kittitas Co & Adrian Lee \\
\hline 56 & 3 & Apr 12,2020 & EconoLodge & Craig Tumer \\
\hline
\end{tabular}


Table 4: The movement of Canada geese during the summer and autumn in the morning

\begin{tabular}{|c|c|c|c|c|c|}
\hline \multirow{2}{*}{ Date } & \multicolumn{2}{|c|}{ Time } & \multicolumn{2}{|c|}{ Temperature $\left({ }^{\circ} \mathrm{C}\right)$} & \multirow{2}{*}{ Population size } \\
\hline & Beginning & Ending & Lowest & Highest & \\
\hline 2020.07 .27 & 8:00 & $8: 01$ & 11.67 & 36.67 & 28 \\
\hline $2020.07 \cdot 30$ & $8: 41$ & $8: 42$ & 18.89 & 37.78 & 3 \\
\hline 2020.08 .03 & $7: 50$ & 8:00 & 13.89 & 32.22 & 32 \\
\hline 2020.08.04 & $7: 50$ & $8: 20$ & 15 & 32.78 & 64 \\
\hline 2020.08 .10 & $7: 53$ & 8:06 & 11.11 & 34.44 & 107 \\
\hline 2020.08.11 & $8: 06$ & $8: 26$ & 13.89 & 32.78 & 32 \\
\hline 2020.08 .13 & $7: 53$ & $8: 40$ & $5 \cdot 56$ & 27.78 & 170 \\
\hline 2020.08 .14 & $8: 31$ & $8: 32$ & 8.89 & 31.11 & 3 \\
\hline 2020.08 .17 & $7: 57$ & $8: 23$ & 16.67 & 38.89 & 591 \\
\hline 2020.08 .18 & $7: 55$ & $8: 38$ & 14.44 & 37.78 & 561 \\
\hline 2020.08 .19 & $7: 55$ & $8: 25$ & 11.67 & 34.44 & 798 \\
\hline 2020.08 .20 & $8: 22$ & $8: 55$ & 21.11 & 31.67 & 123 \\
\hline 2020.08 .21 & $8: 47$ & $8: 50$ & 18.33 & 30.56 & 202 \\
\hline 2020.08 .25 & $8: 38$ & $8: 45$ & 15 & 31.11 & 54 \\
\hline 2020.09 .03 & $8: 54$ & $8: 59$ & 11.67 & 33.89 & 135 \\
\hline 2020.09 .04 & $8: 59$ & 9:08 & 13.89 & 35 & 84 \\
\hline 2020.09 .08 & $8: 14$ & $8: 15$ & 3.89 & $23 \cdot 33$ & 21 \\
\hline 2020.09.18 & $9: 36$ & $9: 37$ & 9.44 & 24.44 & 104 \\
\hline 2020.10 .07 & $8: 13$ & $8: 14$ & 12.22 & 26.11 & 18 \\
\hline
\end{tabular}

Table 5: The movement of Canada geese during the summer and autumn in the evening

\begin{tabular}{|c|c|c|c|c|c|}
\hline \multirow{2}{*}{ Date } & \multicolumn{2}{|c|}{ Time } & \multicolumn{2}{|c|}{ Temperature $\left({ }^{\circ} \mathrm{C}\right)$} & \multirow[t]{2}{*}{ Population size } \\
\hline & Beginning & Ending & Lowest & Highest & \\
\hline 2020.08 .08 & $17: 36$ & 18:09 & 16.11 & 30 & 84 \\
\hline 2020.08 .10 & 18:58 & 19:02 & 11.11 & 34.44 & 62 \\
\hline 2020.08 .11 & 18:04 & 18:05 & 13.89 & 32.78 & 54 \\
\hline 2020.08 .12 & $17: 53$ & 18:19 & 16.11 & 26.67 & 123 \\
\hline 2020.08 .13 & 18:04 & $18: 31$ & $5 \cdot 56$ & $27 \cdot 78$ & 269 \\
\hline 2020.08 .18 & $18: 42$ & $18: 43$ & 14.44 & 37.78 & 19 \\
\hline 2020.08 .28 & $15: 44$ & $15: 50$ & 9.44 & 31.11 & 418 \\
\hline 2020.08 .31 & $17: 36$ & $17: 46$ & 16.67 & 28.33 & 238 \\
\hline 2020.09 .01 & 18:04 & $18: 05$ & 11.67 & 33.33 & 46 \\
\hline 2020.09 .02 & 18:07 & 18:08 & 13.89 & 35 & 206 \\
\hline 2020.09 .15 & $15: 39$ & $15: 40$ & 11.67 & 25 & 59 \\
\hline 2020.10 .03 & $15: 52$ & $15: 53$ & 7.78 & 27.22 & 50 \\
\hline
\end{tabular}

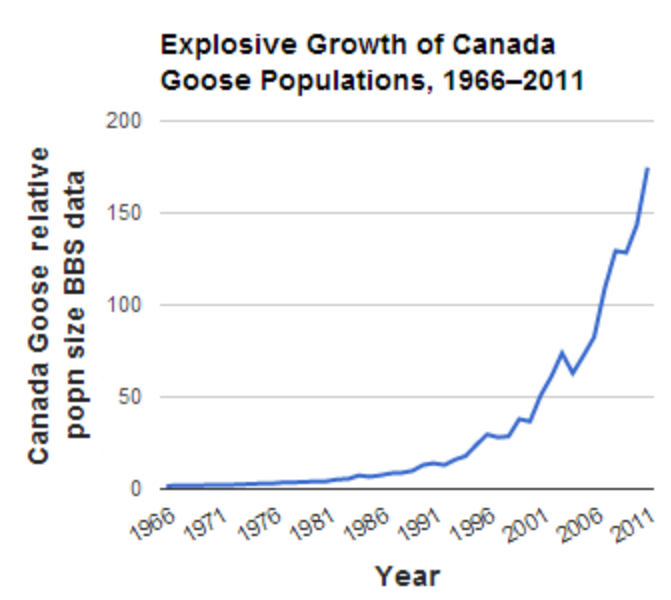

Figure 18: The population size of Canada goose was dramatically increased during 1966 and 2011 (Leonard 2013).

introduced nonmigratory giant subspecies (Anonymous 2014b). The geese were considered protected, though there is a hunting season from September 1 to 15 in the USA, with a daily bag limit of five (Hamrick 2015). The Ohio Department of Natural Resources recommends a number of non-lethal scare and hazing tactics for nuisance geese, but if the methods could not work, they may destroy nests from March 11 through August 31, or conduct a goose roundup or shoot geese.

\section{Suggestions}

The Canada goose is a kind of giant wild bird in North America. It will be helpful to keep the bird population size stable if the natural predators can be protected and natural biological web would work efficiently. The nature itself can keep the ecological substance and energy balanced, and it will help human to pay more attention to develop substantially for future generations.

\section{Current Situation of Wildlife Management in China}

There is a vast territory, complex terrain and climate, high ecological diversity, and rich wildlife resources in China (Ren and Zhaohui 2021). In the ancient China, a relatively perfect foundation had been laid on wildlife management in the Western Zhou Dynasty (about the 11th century BC to $770 \mathrm{BC}$ ), such as the protection of female and young birds and mammals, the establishment of gardens and so on (Chen et al. 1985). After new China was founded, laws, regulations and provisions on wildlife management were 
successively publicized. On November 8, 1988, the Wildlife Protection Act was passed in the fourth meeting of the Standing Committee of the Seventh National People's Congress, which was enforced on March 1, 1989. The attributes and utilization of wildlife were considered in this act (Zhang et al. 2020). With increasing necessities and urgency of wildlife protection, the conflict between the pursuit of immediate profits and the requirements of ecological protection became more and more intense. Therefore, the Wildlife Protection Act was revised in 2018 (The Wildlife Protection Act in China 2020), and the principles of "protection priority, standardized utilization and strict supervision" were emphasized.

Since 21st century, the outbreak of large-scale epidemic diseases, including SARS in 2003, MERS in 2015, Ebola in 2019, and COVID-19 from 2019 to now, the close relationship between the improper use of wild animals and the risk of public health and safety became more serious than before (Zhang and Zhigang 2021; Stawicki et al. 2020). The Decision on Comprehensively Banning Illegal Wildlife Trading, Getting Rid of the Negative Habit of Eating Wild Animals Indiscriminately, and Effectively Protecting People's Health and Safety was passed in the 16th session of the Standing Committee of the 13th National People's Congress on February 24, 2020 (Standing Committee of the National People's Congress 2020). "Illegal hunting, killing, trading and eating of wild animals should be severely punished" was clearly pointed out in the Government Work Report in May 2020. The clear tasks were put forward in these strategies to improve the management of ecological environment and wildlife protection, which fully reflects the attached importance of Chinese government on the rational utility of wildlife resources.

The utilization of wildlife resources was managed in the mode of classification

At present, scientific research, public exhibition, medicinal and edible usages are the four main legal ways of wildlife resources in Chinese legation system ( $\mathrm{Yu}$ and Siying 2020a). The wild animals are managed into different classifications according to different objects and ways of utilization (Zhong 2008).

The wild animals could be divided into two categories in "the Wildlife Protection Act": key protected wild animals and terrestrial wild animals with important ecological, scientific and social values (Three Values Animals). Among them, the key protected wild animals are divided into national key protection level and local key protection level (Anonymous 2020e).

The utility of national key protected wildlife is limited to scientific research, public exhibition and other public purposes and special uses such as medicine. Whether the wild or artificial population would be used, it must be approved by the relevant department in charge of wildlife protection, and the corresponding special identification and quarantine inspection should be conducted (Anonymous 2020e). The artificial population with mature and stable artificial breeding technology and listed in the list of national key protected wild animals for artificial breeding could be sold and utilized with Artificial Breeding License, special identification and corresponding quarantine certificate. However, since February 24, 2020, the Standing Committee of the National People's Congress issued the Decision on Comprehensively Banning Illegal Wildlife Trading, Getting Rid of the Negative Habit of Eating Wild Animals Indiscriminately, and Effectively Protecting People's Health and Safety, the wild animals in the list of artificially bred National Key Protected Wild Animals are not edible.

For the utility of Local Key Protected Wildlife and Three Values Animals, the artificial breeding population should be applied in scientific research, public display and medical use, and it can be used with the legal certificate of hunting, and import and export quarantine certificate (Anonymous 2020e). Moreover, the relevant laws and regulations of drug administration should be obeyed if the wildlife would be in medical usage. The restrictions on the use of non-rare and non-Three Values Animals are not strict like key protected wildlife because they are not within the protection scope of the Wildlife Protection Act (Anonymous 2020e).

This scoping for the wildlife based on rarity and value essentially reflects the thoughts of "key protection" rather than "comprehensive protection".

License system, special identification system and quarantine system are adopted in the management measures of wildlife utilization

Article 33rd in the Wildlife Protection Act in China (Anonymous 2020e), the special hunting license or artificial breeding certificate, copy of them or special mark, and quarantine certificate should be prepared if a national key protected wildlife and its products from wild environment or artificial population would be transported, carried or delivered across the county. The marking technical services, management and identification agencies were provided in the Notice on the Enterprises Produced Some Wildlife Products Should Be Cleaned up and Rectified and Carried out the Pilot Marking was issued by the State Forestry Administration and the State Administration of Industry and Commerce in 2003. The regular inspection system was set in Measures for the Administration of Domestication and Breeding Licenses of Wildlife under Special State Protection. The Measures for the Administration of Domestication and Breeding Licenses for National Key Protected Wildlife under Special State Protection stipulates a regular inspection system.

The wildlife management system is dominated by Forestry departments, supplemented by other relevant administrative agencies and nongovernmental organizations

National Forestry and Grassland Administration is responsible for terrestrial wildlife, and Bureau of Fisheries 
(in Ministry of Agriculture and Rural Affairs) is responsible for aquatic wildlife (Anonymous 2020e), and other relevant departments are responsible to supervise and manage the related issues in the process of wildlife utilization according to the division of responsibilities in Chinese current wildlife management system. In practice, wildlife management mainly involves the departments of ecological environment, market supervision, agriculture, health, police and customs. Specifically, National Forestry and Grassland Administration and Bureau of Fisheries are mainly responsible for formulating and updating the List of National Key Protected Wildlife and the List of Three Values Animals, and also responsible for the approval of utilization of National Protected Wildlife and the issuance of special identification, the License for Artificial Breeding of Wildlife and the issuance of special identification, etc. The Department of Ecology and Environment is mainly responsible for the work related to biodiversity protection and the supervision of ecological protection red line and nature reserves. The Department of Market Supervision is responsible for supervising the business, utilization and advertising of wild animals. In addition to protecting aquatic wildlife, Ministry of Agriculture and Rural Affairs also manage alien species. National Health Commission focuses on the epidemic work and drug management of wild animals. The Ministry of Public Security is mainly responsible for the law enforcement of wildlife crimes (Zhang et al. 2020). General Administration of Customs is responsible for the control of the inspection and quarantine of entry-exit wild animals and plants and other transnational use of wild animals. There are overlapping responsibilities among different departments, with some departments are responsible for both management and supervision, which affects the effective implementation of the Wildlife Protection Act to a great extent (Yu et al. 2020b).

\section{Conclusion}

The chapter includes the following five parts. Some important scientific definitions and explanations were listed in wildlife management, such as "wildlife" and "wildlife management" etc. in the first part. The implication of "wildlife" could be changed with the time going. COVID-19, global climate change and pollution are threatening wildlife management and public health, which were described in the second part. COVID-19 pandemic caused big disaster for humans in recent years, and the glacier melting in the southern pole and colorful algae show the global consistent warming. Water pollution and algal bloom events are warning humans, so harsh environments are faced with now. It is urged to improve the efficiency of wildlife management. Three cases on conflict between humans and wildlife in the USA and China are in the third part. Both humans and wildlife need to survive in the world, so it is necessary to control the population size of wildlife in the nature by different strategies. The wildlife observation practice in the USA is in the fourth part. The free terrestrial wildlife in the backyard, campus and suburb showed the efficient wildlife management in the USA. The Canada geese were observed in Ellensburg, Washington throughout the year, and they may locate the flying direction by sun and stars, and summer movement may help save Canada goose from being hunted in the hunting season. The current situation of wildlife management in China is in the fifth Part. More and more strict policies and acts have been implemented to improve the level of wildlife management in China to protect wildlife.

\section{REFERENCES}

Abd Rabou AN, 2020. How is the COVID-19 outbreak affecting wildlife around the world? Open Journal of Ecology 10: 497-517.

Adams CM et al., 2018. Assessing the economic consequences of harmful algal blooms: A summary of existing literature, research methods, data, and information gaps. In: Harmful Algal Blooms: A Compendium Desk Reference, 1st Edition. Shumway SE, Burkholder JM, Morton SL (editors). Hoboken, NJ: John Wiley and Sons Ltd, pp: 337-354.

Allan JR, 200o. The costs of bird strikes and bird strike prevention. Human Conflicts with Wildlife: Economic Considerations 18: 147-153.

Anonymous, 2013. The Bismarck Tribune. Obituary: Forrest Lee. Bismarck, North Dakota. 2013-02-07.

Anonymous, 2014a. 'Putin's tiger' may spend winter in China. http://www.china.org.cn/environment/201410/18/content_33804566.htm Xinhua, 2014-10-15.

Anonymous, 2014b. The Humane Society of the United States. Why Do Canada Geese Like Urban Areas? 2014-02-20.

Anonymous, 2015. The Lima News. Ohio reports increase in Canada geese population. via Associated Press Dayton. 2015-03-09.

Anonymous, 2017. Report on the sustainable development strategy of wildlife farming industry in China. 2017. Project team of "Research on sustainable development strategy of China's wildlife farming industry". (in Chinese).

Anonymous, 2018. Here is the perfect spot for a birds' inner compass. University of Southern Denmark. Science Daily. https://www.sciencedaily.com/releases /2018/02/180207120617.htm

Anonymous, 2020a. Make a record! The temperature in Antarctica reaches $20.75^{\circ} \mathrm{C}$ for the first time, and there will be more extreme weather in the future. International Hot Vision Release time: 2020-02-14. https://baijiahao.baidu.com/s?id=165850110150699885 o\&wfr $=$ spider\&for $=p c$

Anonymous, 2020b. There are 2 million methane emission points in the Arctic! Permafrost thaws, global warming falls into a vicious circle. New Observation of Universe Science, Release time: 2020o2-16. https://baijiahao.baidu.com/s?id=165865691630 9549521\&wfr=spider\&for $=p c$

Anonymous, 2020c. Antarctic big wave, large-scale "red snow", the earth may be in big change, related to human beings? Global Science Cat, Release time: 
2020-02-27. https://baijiahao.baidu.com/s?id=1659 $688763093975612 \& w f r=$ spider $\&$ for $=p c$

Anonymous, 2020d. https://ebird.org/map/cangoo4? neg=true\&env.minX=\&env.min $Y=\& e n v \cdot \operatorname{maxX}=\& e n v$. $\mathrm{maxY}=\& \mathrm{zh}=$ false \&gp=false \&ev $=Z \& \mathrm{mr}=1-12 \& b m o=1 \& \mathrm{e}$ $\mathrm{mo}=12 \& \mathrm{yr}=\mathrm{all} \& \mathrm{byr}=1900 \& \mathrm{eyr}=\mathbf{2 0 2 0}$

Anonymous, 2020e. The Wildlife Protection Act in China. http://www.zfs.moa.gov.cn/flfg/202002/t20200217_63 37193.htm 2020- 2-17.

Anonymous, 2021. Watermelon-like red snow appears in Antarctica, and it smells like watermelon, but it has nothing to do with watermelon. Popular Science World, Release time: 02-2021. https://baijiahao.baidu. $\mathrm{com} / \mathrm{s}$ ?id=1692273189718103547\&wfr=spider\&for=pc).

Backer LC et al., 2015. Cyanobacteria and algae blooms: review of health and environmental data from the Harmful Algal Bloom-Related Illness Surveillance System (HABISS) 2007-2011. Toxins (Basel) 7: 10481064 .

Bailey JA, 1984. Principles of Wildlife Management. John Wiley \& Sons.

Bergstrom CT and Dugatkin LA, 2016. Evolution. 2nd Edition. W. W. Norton \& Company.

Berry MA et al., 2017. Cyanobacterial harmful algal blooms are a biological disturbance to Western Lake Erie bacterial communities. Environmental Microbiology 19: 1149-1162.

Borsky S et al., 2020. CITES and the zoonotic disease content in international wildlife trade. Environmental and Resource Economics 76: 1001-1017.

Bourret V et al., 2020. Past, present and future contributions of evolutionary biology to wildlife forensics, management and conservation. Evolution Application 13: 1420-1434.

Carroll $\mathrm{C}$ et al., 2010. Geography and recovery under the U.S. Endangered Species Act. Conservation Biology 24: 395-403.

Caughley G, 1966. Mortality patterns in mammals. Ecology 47: 906-918.

Chen D et al., 1985. The law of wildlife management in ancient China. Chinese Journal of Wildlife 1: 15-18.

Chinadaily, 2021. Asian elephant herd on move in Yunnan province. 2021. http://www.chinadaily.com.cn/a/ 202105/28/WS6oboa72da31024adobac22f4.html 2021o6-01.

Chinanews 2021. The global epidemic of Novel coronavirus pneumonia in real time. Chinanews App. https://www.Chinanews.com/m/34/2020/0318/1388/gl obalfeiyan.html 2021-03-18.

Cleaveland S et al., 2007. Overviews of pathogen emergence: Which pathogens emerge, when and why. Current Topics in Microbiology and Immunology 315: 85-111.

Dhama K et al., 2020. Coronavirus disease 2019-COVID19. Clinical Microbiology Review 33: eooo28-20.

Dieter $\mathrm{C}$ et al., 2010. Late summer movements by giant Canada geese in relation to a September hunting season. Human-Wildlife Interactions 4: 232-246.

Fairbrother A, 2009. Federal environmental legislation in the U.S. for protection of wildlife and regulation of environmental contaminants. Ecotoxicology 18: 784790.

Frutos R et al., 2021. Emergence of bat-related betacoronaviruses: Hazard and risks. Frontiers in Microbiology 12: 591535 .

Fryxell JM et al., 2014. Wildlife Ecology, Conservation, and Management, 3rd Edition. Wiley-Blackwell, USA.

Hadidian J, 2015. Wildlife in U.S. cities: Managing unwanted animals. Animals (Basel) 5: 1092-1113.

Hamrick B, 2015. Canadian geese get violent during nesting, population on the rise. WLWT. 2015-05-06.

Hanson HC, 1997. The Giant Canada Goose. 2nd Edition. Southern Illinois University Press, USA.

Hedman HD et al., 2021. Host diversity and potential transmission pathways of SARS-CoV-2 at the humananimal interface. Pathogens 10: 180.

Hoham RW and Remias D, 2020. Snow and glacial algae: A review. Journal of Phycology 56: 264-282.

Holappa K, 2020. Wildlife agents make difficult decision to use lethal force on cougar. Daily Record. https://www.dailyrecordnews.com/news/wildlife-age nts-make-difficult-decision-to-use-lethal-force-oncougar/article_cfed17ba-f3e5-5c53-81fa-796467fi5fdc. html 2020-05-15.

Hou Y et al., 2020. Estimating the cultural value of wild animals in the Qinling Mountains, China: A choice experiment. Animals (Basel) 10: 2422.

$\mathrm{Hu} \mathrm{Y}$ et al., 2020. A bird strike risk assessment model and its application at Ordos Airport, China. Scientific Reports 10: 19627.

Keatts LO et al., 2021. Implications of zoonoses from hunting and use of wildlife in North American arctic and boreal biomes: Pandemic potential, monitoring, and mitigation. Frontiers in Public Health 9: 627654.

Krausman PR and Cain III JW, 2013. Wildlife Management and Conservation: Contemporary Principles \& Practices. The Johns Hopkins University Press 2715 North Charles Street Baltimore, Maryland.

Landys MM et al., 2004. Plasma corticosterone increases during migratory restlessness in the captive whitecrowned sparrow Zonotrichia leucophrys gambelli. Hormones and Behavior 46: 574-581.

Leonard P, 2013. Where did all those Canada geese in town come from? https://www.allaboutbirds.org/ news/canada-goose-resident-vs-migratory

Leopold A, 1933. Game Management. Charles Scribner's Sons, New York, USA.

Liew $\mathrm{JH}$ et al. 2021. International socioeconomic inequality drives trade patterns in the global wildlife market. Science Advances 7: eabf7679.

Liu L, 2021. Harvard's latest prediction: COVID-19 will last until 2025! Leifeng net. https://news.mydrivers. com/1/683/683985.htm 2021-05-28.

Lopez-Lago $\mathrm{M}$ et al., 2017. A predictive model for risk assessment on imminent bird strikes on airport areas. Aerospace Science and Technology 62: 19-30.

MacHugh DE et al., 2017. Taming the past: Ancient DNA and the study of animal domestication. Annals of Reviews in Animals and Biosciences 5: 329-351. 
Mallah SI et al., 2021. COVID-19: Breaking down a global health crisis. Annals of Clinical Microbiology and Antimicrobials 20: 35 .

Martin M and Foote-Martin S, 2018. Canada Goose - Early Summer Migration. Friday Feathered Feature. https://madisonaudubon.org/fff/2018/6/1/canadagoose-early-summer-migration 2018-o6-o1.

Malcom JW and Li YW. 2015. Data contradict common perceptions about a controversial provision of the US endangered species act. Proceedings of the National Academy of Sciences of the United States of America 112: 15844-15849.

McCarthy O, 2015. 8 creative ways to reduce humanwildlife conflict. https://howtoconserve.org/2015/12/ 04/human-wildlife-conflict/.

Metson GS et al., 2017. Linking terrestrial phosphorus inputs to riverine export across the United States. Water Research 124: 177-191.

Messinger LN et al., 2019. Mortality, perception, and scale: Understanding how predation shapes space use in a wild prey population. PLoS One 14: e0222272.

Miller FP et al., 2011. Fish and Wildlife Coordination Act. United States, United States Fish and Wildlife Service, United States Secretary of the Interior.

Nangongxiaopang, 2021. What happened in Xishuangbanna on earth and cause the Asian elephants left? https://baijiahao.baidu.com/s?id= 1701897368296703977\&wfr=spider\&for=pc. 2021-o6-o7 (in Chinese).

Norman RL et al., 1975. Using wildlife values in benefit/cost analysis and mitigation of wildlife losses. Colorado Division of Wildlife, Denver, USA.

Noss FR et al., 1997. The science of conservation planning: Habitat conservation under the endangered species act. Journal of Wildlife Management 64: 891893.

Paerl HW et al., 2011. Controlling harmful cyanobacterial blooms in a world experiencing anthropogenic and climatic-induced change. Science of the Total Environment 409: 1739-1745.

Perrings $C$ et al., 2018. The economics of infectious disease, trade and pandemic risk. EcoHealth 15: 241243.

Rahman MT et al., 2020. Zoonotic diseases: Etiology, impact, and control. Microorganisms 8: 1405.

Ren $\mathrm{H}$ and Zhaohui G, 2021. Progress and prospect of biodiversity conservation in China. Ecological Science 40: 247-252.

Rizzolo JB, 2020. Wildlife farms, stigma and harm. Animals (Basel) 10: 1783 .

Roberts VA et al., 2020. Surveillance for harmful algal bloom events and associated human and animal illnesses - One Health harmful algal bloom system, United States, 2016-2018. MMWR Morbidity, Mortality Weekly Reports 69(50): 1889-1894.

Sèbe $\mathrm{M}$ et al., 2020. Reducing whale-ship collisions by better estimating damages to ships. Science of the Total Environment 713: 136643.

Shangfangwen Q, 2021. Pictures of wild elephants sleeping and resting by Unmanned Aerial Vehicle
(UAV): Really nice. https://news.mydrivers.com/1/ 761/761942.htm 2021-06-07 (in Chinese).

Shanxi Evening News, 2020. The corpses lie all over the countryside! Afraid of being infected, Denmark has ordered 17 million minks to be killed all over the country. 2020. https://baijiahao.baidu.com/s?id= 1683074087464209532\&wfr=spider\&for=pc 2020-11-12.

Shao J et al., 2014. Interactions between algicidal bacteria and the cyanobacterium Microcystis aeruginosa: Lytic characteristics and physiological responses in the cyanobacteria. International Journal of Environmental Science and Technology 11: 469-476.

Sophie H, 2020. Every month, 200 billion face masks and gloves are going into the environment. https://www.greenmatters.com/p/face-masks-gloveslitter-coronavirus. Accessed on 2020-07-08.

Standing Committee of the National People's Congress, 2020. Decision on comprehensively banning the illegal trade in wild animals, getting rid of the bad habit of eating wild animals indiscriminately, and effectively ensuring the people's health and safety. 2020-02-24.

Stawicki SP et al., 2020. The 2019-2020 novel coronavirus (severe acute respiratory syndrome coronavirus 2) pandemic: A joint American college of academic international medicine-world academic council of emergency medicine multidisciplinary covid-19 working group consensus paper. Journal of Global Infectious Diseases 12: 47-93.

$\mathrm{Su} \mathrm{K}$ et al., 2020. Human-elephant conflicts and villagers' attitudes and knowledge in the Xishuangbanna Nature Reserve, China. 2020. International Journal of Environment Research and Public Health 17: 8910.

Su XM et al., 2017. Response of bacterial communities to cyanobacterial harmful algal blooms in Lake Taihu, China. Harmful Algae 68: 168-177.

Šulčius S et al., 2017. The profound effect of harmful cyanobacterial blooms: From food-web and management perspectives. Science of the Total Environment 609: 1443-1450.

Treves A et al., 2017. Predators and the public trust. Biological Reviews 92: 248-270.

Wells ML et al., 2020. Future HAB science: Directions and challenges in a changing climate. Harmful Algae 91: 101632.

WHO, 2020a. Asia Pacific Strategy for Emerging Diseases: 2010. Manila: World Health Organization (WHO) Regional Office for the Western Pacific. https://iris.wpro.who.int/bitstream/handle/10665.1/78 19/ 9789290615040_eng.pdf.

WHO, 202ob. WHO Health Topic Page: Zoonoses. https://www.who.int/ topics/zoonoses/en/.

Wolfe $\mathrm{N}$ et al., 2007. Origins of major human infectious diseases. Nature 447: 279-283.

Woodyatt ACNN, 2020. Snow is turning green in Antarctica -- and climate change will make it worse. https://edition.cnn.com/2020/o5/21/world/greensnow-antarctica-climate-change-intl-scli-scn/index. html. 
Yu WX and Siying H, 2020a. The improvement of legal mechanism of wildlife management - in the sight of perspective of institutional risk. Journal of Nanjing University of Technology (Social Science Edition) 48: $1-7$.

Yu WX et al., 202ob. The improvement of wildlife protection legal system from the perspective of public health and safety. Journal of Nanjing University of Technology 48: 17-20.

Zhang $\mathrm{H}$ and Zhigang $\mathrm{T}$, 2021. Changes of cooperation network among government departments in emergency management of public health. Journal of Wuhan University (Philosophy and Social Sciences Edition) 74: 114-126.
Zhang $\mathrm{H}$ et al., 2018. Dynamics of bacterial and fungal communities during the outbreak and decline of an algal bloom in a drinking water reservoir. International Journal of Environmental Research and Public Health 15: 361.

Zhang L et al., 2020. Implementing the strictest wildlife protection: China's current situation and reform direction. Environmental Management in China 12: 5-19.

Zhong L, 2008. Study on the standardization and standard system of wildlife protection in China. Forestry Science and Technology 3: 28-30.

Zhou H, 2014. Putin's tiger believed to be photographed in China. http://europe.chinadaily.com.cn/china/ 2014-11/14/content_18912280.htm. 